\title{
Improving Surveillance Across the CEMAC Region
}

\author{
Plamen Iossifov, Noriaki Kinoshita, Misa \\ Takebe, Robert York, and Zaijin Zhan
}




\title{
IMF Working Paper
}

\author{
African Department
}

\section{Improving Surveillance Across the CEMAC Region}

\section{Prepared by Plamen Iossifov, Noriaki Kinoshita, Misa Takebe, Robert York, and Zaijin Zhan ${ }^{1}$}

Authorized for distribution by John Wakeman-Linn

November 2009

\begin{abstract}
This Working Paper should not be reported as representing the views of the IMF.

The views expressed in this Working Paper are those of the author(s) and do not necessarily represent those of the IMF or IMF policy. Working Papers describe research in progress by the author(s) and are published to elicit comments and to further debate.

In this paper, we consider the design of the surveillance, and, in particular, the fiscal criteria in the Central African Economic and Monetary Community (CEMAC) with the view to ensuring they are consistent with internal and external sustainability. This consistency is important within a monetary union because fiscal policy is the primary instrument through which national governments can influence macroeconomic performance. We comment on how surveillance might be improved by broadening the region's current criteria through alternative fiscal indicators, some focus on the scope and nature of external shocks, and attention to the consistency of policies in assuring the viability of the union and its fixed exchange rate regime.
\end{abstract}

JEL Classification Numbers: $\quad$ E5, E6, F5, H5, H6

Keywords: monetary policy, fiscal policy, non-oil primary deficit, sustainability, economic cycles and shocks, foreign reserves

Author's E-Mail Address: ryork@imf.org

\footnotetext{
${ }^{1}$ An earlier draft of this paper was presented in a seminar at the CEMAC's regional central bank in Yaoundé, Cameroon in September 2009. We would like to acknowledge the helpful advice and comments from John Wakeman-Linn, Tidiane Kinda, Oscar Melhado, and Marcos Poplawski; and we are grateful to Anne Grant for editorial assistance. Any errors, however, are our own.
} 


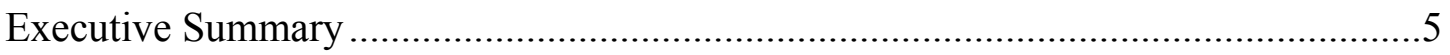

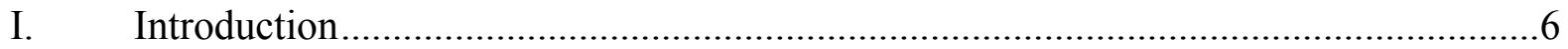

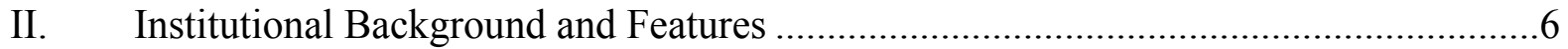

A. Macroeconomic Policies in the CEMAC Region ...........................................13

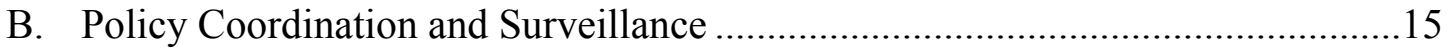

III. Improving the Measures of Fiscal Surveillance.................................................17

A. Fiscal Policy Objectives and Indicators........................................................... 17

B. Indicators of Policy Stance and Policy Change .................................................18

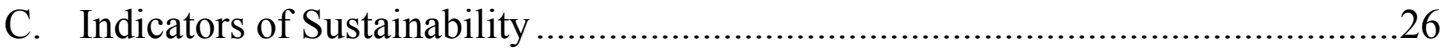

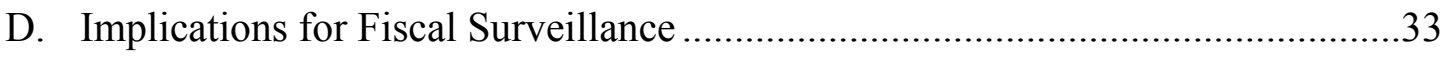

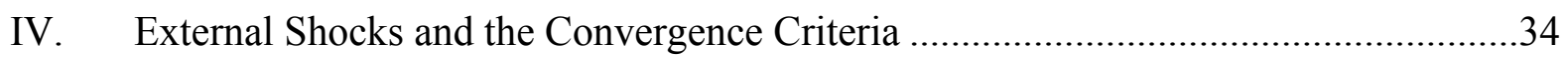

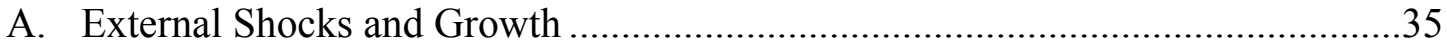

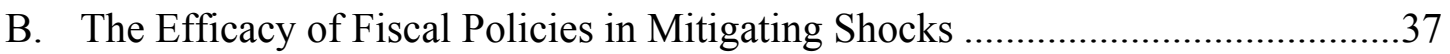

C. Implications for Regional Surveillance ................................................... 40

V. External Stability Considerations and Regional Surveillance .................................42

A. Consistency of the CEMAC Fiscal Convergence Criteria with External Stability ...........................................................................................4 43

B. The Desirability of a Foreign Reserves Target..............................................48

C. Long-run Considerations in Regional Surveillance.........................................49

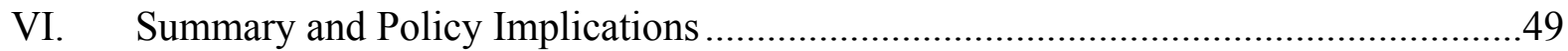

Boxes

1. Brief Economic History of the Central African CFA Zone .....................................

2. Overview of the Optimum Currency Area Literature ............................................. 12

3. BEAC Monetary Programming ......................................................................... 14

4. Characteristics of Oil Revenue in the CEMAC ........................................................15

5. CEMAC Convergence Criteria .........................................................................16

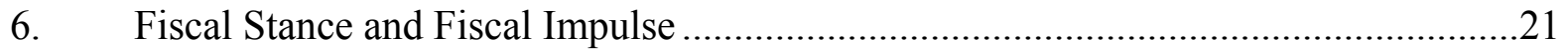

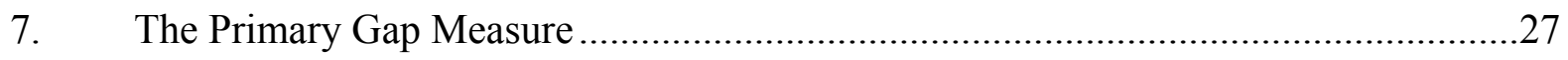

8. Constant Fiscal Expenditure Rule for Oil Producing Countries .................................31

9. Measuring the Impact of Exogenous Shocks on the Non-oil Economy .....................37

10. Measuring the Impact of Counter-Cyclical Fiscal Policies on the

Non-oil Economy. 
Tables

1. CEMAC Fiscal Developments and the Fiscal Convergence Criteria, 1998-2008 ......20

2. A Comparison of CEMAC Fiscal Indicators, 2000-08 (in percent of GDP) .............23

3. A Comparison of CEMAC Fiscal Indicators, 2000-08

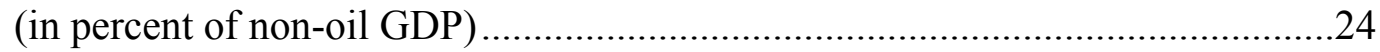

4. Primary Gap Measures Across the CEMAC, 1998-2008 …...................................27

5. CEMAC Long-term Macroeconomic Assumptions ..............................................29

6. CEMAC Average Sustainable Non-oil Primary Deficit Under Different Fiscal

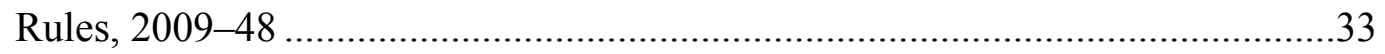

7. Real Non-oil GDP Growth in CEMAC Countries, 1980-2008...............................34

8. Correlation of Real GDP Growth Among CEMAC Countries, 1980-2008...............34

9. Triggers of Recessions in CEMAC Countries, selected periods ..............................35

10. Correlation Between Non-oil Real GDP and External Factors, 1980-2008 ..............36

11. Correlation Between GDP, Public Expenditure, and Non-oil Revenue .....................38

12. Average Share of Non-oil Revenue and Expenditure in Non-oil GDP, 1980-2008 ...39

13. Variance Decomposition of Real GDP by Types of Shocks ...................................42

14. CEMAC Share of Oil Revenue in Total Revenue and Correlation Between

Fiscal and External Balances ....................................................................45

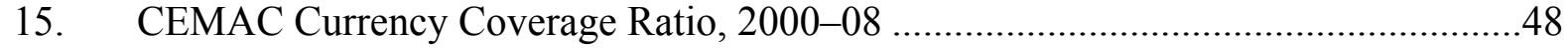

16. CEMAC Gross Official Reserves, 2000-08 .......................................................48

Figures

1. CEMAC Real and Fiscal Developments, 1969-2008_........................................8

2. CEMAC Terms of Trade and Balance of Payments Developments, 1969-2008 .........9

3. CEMAC Net International Reserve Coverage of Imports, 1995-2008 .....................11

4. CEMAC Fiscal Policy and Procyclicality vis-à-vis Oil Revenue, 1980-2008 ............15

5. Nominal and Real Crude Oil (Spot) Prices, 1970-2014 ........................................19

6. CEMAC Non-oil Real GDP Growth and the Fiscal Impulse, 1995-2008 ................25

7. CEMAC External Debt and the Primary Gap, 1998-2008 .......................................28

8. CEMAC Sustainable Non-oil Primary Deficit Under Different Fiscal Rules, 2009-13 ................................................................................. 32

9. CEMAC Sensitivity of the Sustainable Non-oil Primary Deficit to Oil Prices Under a Permanent Income Hypothesis, 2009-13 ..............................................32

10. Terms of Trade and Real Effective Exchange Rates, 1980-2008 ............................36

11. Impulse Response of Output to a One Standard Deviation Change in Terms of Trade and Real Effective Exchange Rate Shocks ...........................................38

12. Impulse Response of Output to a One Standard Deviation Change in Revenue and Spending Shocks

13. CEMAC Overall Fiscal Balance and External Current Account Balance, 1996-2008 
14. CEMAC Countries Overall Fiscal Balance and External Current Account Balance, 1996-2008

15. CEMAC Foreign Assets of BEAC and Government Deposits at BEAC, 1995-2008

Appendix: Linkages Between Fiscal and Monetary Policies in a Non-Renewable Resource Producer under a Fixed Exchange Rate .....

References. 


\section{EXECUTIVE SUMMARY}

In this paper, we consider the design of the surveillance, and, in particular, the fiscal criteria in the Central African Economic and Monetary Community (CEMAC) with a view to ensuring they are consistent with internal and external sustainability. This consistency is important within a monetary union because fiscal policy is the primary instrument through which national governments can influence macroeconomic performance. We comment on how surveillance might be improved by broadening the region's current criteria through alternative fiscal indicators, some focus on the scope and nature of external shocks, and attention to the consistency of policies in assessing the viability of the union and its fixed exchange rate regime.

In taking a broad approach to regional surveillance, we find that the CEMAC's convergence criteria are rather limited and provide an incomplete picture of the policies and other forces acting, and offer little insight on whether policies are consistent with goals of the monetary union. To be more effective, the CEMAC's surveillance agenda could be sharpened in a number of ways.

We would argue that fiscal surveillance at both the regional and country level should not rely entirely on the current convergence criteria. Instead, the fiscal indicators excluding oil revenue, such as the non-oil fiscal stance, non-oil fiscal impulse, and non-oil primary balance, should receive central attention. In this regard, we welcome the CEMAC Commissions' introduction of an adjustment criterion on the non-oil basic fiscal balance but to make it effective, this criterion would need to be refined. Ideally, each economy's cyclical position should be considered as well, although we recognize the practical difficulties in applying cyclical adjustments in a transparent and uniform way across all member countries. With five of the six countries being oil-producers long-term fiscal sustainability should also be of concern, which could be monitored through analysis based on simple fiscal rules.

CEMAC countries have been faced with external shocks that have been shown to have a significant and variable impact across member countries, which complicate economic and especially fiscal policies. Indeed, the current fiscal convergence criteria do not address the procyclical nature of CEMAC fiscal polices, which can exaggerate the impact of external shocks. Since discretionary fiscal policy is demonstrated to have the ability to mitigate the impact of external shocks across the region, it is important to take this factor into account when assessing and formulating the relevant convergence criteria.

Also, CEMAC's surveillance agenda will need to consider the impact of fiscal policy on external stability, in light of the fixed exchange rate regime. Here, building sufficient reserve coverage is important and in periods of high world oil prices when there is a windfall of oil revenue. When setting a desirable reserve target level, consideration could be given to creating space for the fiscal stance to respond to changes in external (as well as domestic) conditions. To address long-term external stability, the regional surveillance exercise could cover structural aspects of fiscal policy so that tax and spending system would be supportive of capital accumulation and productivity gains in reproducible sectors.

Ultimately, the external viability of the monetary union and its fixed exchange rate depends on the strength of fiscal policies and structural reform to build vibrant and viable non-oil sectors in the member countries. Only in this way will the union generate enough foreign exchange to finance the imports needed to maintain moderate levels of growth and real income. 


\section{INTRODUCTION}

In this paper, we consider the design of the surveillance, and, in particular, the fiscal criteria in the Central African Economic and Monetary Community (CEMAC) with a view to ensuring they are consistent with internal and external sustainability. This consistency is important within a monetary union because fiscal policy is the primary instrument through which national governments can influence macroeconomic performance. We comment on how surveillance might be improved by broadening the region's current criteria through alternative fiscal indicators, extending the analysis to better cover the current economic environment in member countries, including the scope and nature of external shocks affecting them, and attention paid to the consistency of policies in assuring the viability of the union to support its fixed exchange rate. As it stands, the surveillance agenda of the CEMAC Commission and its focus on a narrow set of convergence criteria fails to accurately assess macroeconomic policy developments from a short- and long-term perspective.

We start with an overview of CEMAC structure in Section II, juxtaposing its features with the findings of the optimum currency area literature to see how the region compares, and the regional surveillance framework put in place to ensure their compatibility. In Section III we assess fiscal performance based on an alternative set of indicators that could be used by the CEMAC Commission, to provide better insights into policy developments and sharpen surveillance. In Section IV we elaborate on the nature of external shocks across the region to better understand how CEMAC countries have been affected and how they might respond to mitigate them. A clearer understanding of the transmission mechanisms and forces acting would put the surveillance agenda into better focus, and give context to performance when measured against the current convergence criteria which lacks such focus. In Section V, we discuss the importance of external viability, which is critical to safeguarding the fixed exchange rate regime and how better monitoring of fiscal and foreign reserve developments could help. We summarize our results and offer some policy implications in Section VI.

\section{INSTITUTIONAL BACKGROUND AND FEATURES}

The CEMAC is a customs and monetary union of Cameroon, the Central African Republic (C.A.R.), Chad, Republic of Congo (Congo), Equatorial Guinea, and Gabon. It was established in 1994 as a culmination of a long process of economic integration in Central Africa (see Box 1). Its objectives are to create a common market based on the free movement of goods and services, capital, and labor, and to harmonize business laws and coordinate economic policies. CEMAC members use a common currency, the CFA franc, which is pegged to the euro at CFAF 656 per euro. The CFA franc is issued by the regional central bank (the Central Bank of Central African States, BEAC). 


\section{Box 1. Brief Economic History of the Central African CFA Zone}

Prior to 1946 the African territories colonized by France used as currency the French franc, which was then replaced by the CFA Franc issued by the central bank for French overseas territories. After gaining their independence in the 1960s, the Central African members of the CFA franc zone kept the CFA franc as their common currency but control over the currency gradually shifted from France to CEMAC governments, although the French treasury continued to guarantee CFA franc convertibility.

Through the mid-1980s the CFA franc zone economies recorded higher real GDP growth and significantly lower inflation than other sub-Saharan African economies while avoiding the buildup of major macroeconomic imbalances. Their relatively good performance was supported by favorable terms of trade, driven by rising international commodity prices in US dollars and a weakening of the French franc relative to the US dollar. Equatorial Guinea, a former Spanish colony, adopted the CFA franc in 1984.

In contrast, in the following decade the terms of trade deteriorated as international commodity prices fell and France adopted the post-1985 policy of a strong franc, which resulted in mounting fiscal and current account deficits across the CEMAC. As structural reforms aimed to improve competitiveness and rein in the deficits proved unsuccessful, the area suffered a protracted decline. The regulatory ceilings on direct central bank financing of fiscal deficits were not a binding constraint; governments ran arrears to domestic suppliers and creditors and borrowed from abroad and (directly or through public enterprises) from commercial banks, which in turn had access to central bank financing. The result was a build-up of external debt, illiquidity in domestic transactions, and numerous bank insolvencies.

A 50 percent devaluation of the CFA franc in 1994 and improving terms of trade helped restore moderate economic growth to the region (text Figures 1 and 2). The external sector was supported by aid from France and Paris Club debt rescheduling and cancellation. Instead of undermining the cohesion of the CFA franc zone, the 1994 devaluation gave new impetus to regional integration, and the CEMAC was established that year. The objective was to create a common market based on free movement of goods and services, capital, and labor; harmonize business laws; and coordinate economic policies. CEMAC members also ceded their bank supervisory powers to a regional body (the Central African Banking Commission, COBAC).

With the launch of the euro in 1999, CFA franc parity with the French franc was translated into a parity with the euro by applying the irrevocable exchange rate between the French franc and the euro. 
Figure 1. CEMAC Real and Fiscal Developments, 1969-2008
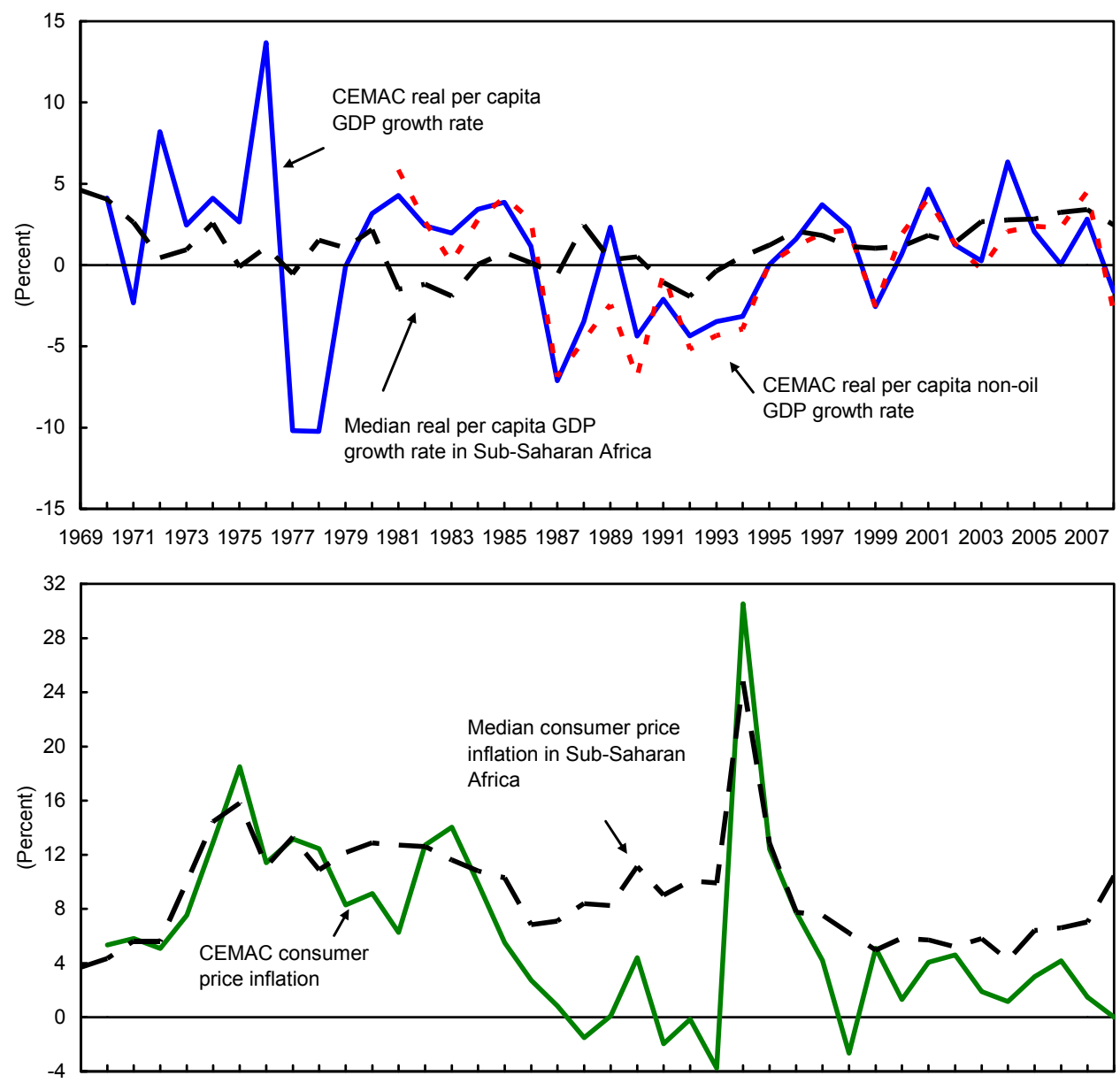

19691971197319751977197919811983198519871989199119931995199719992001200320052007

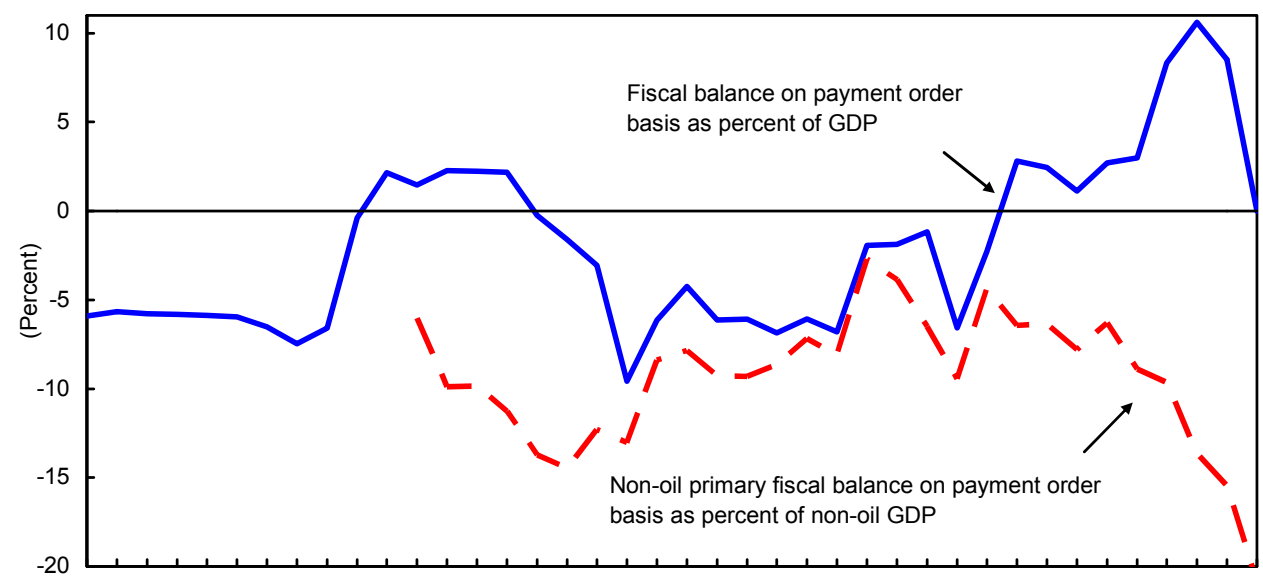

19691971197319751977197919811983198519871989199119931995199719992001200320052007

Sources: IMF's WEO database; national authorities; and IMF staff estimates.

Note: Presented ratios and growth rates are constructed using CEMAC-wide aggregates of variables in the numerator and denominator. The CEMAC CPI is a weighted average of CEMAC members' CPIs, using as weights their shares in CEMAC's GDP in purchasing power parity US\$. The 2006 fiscal balance estimates for Cameroon replace actual grants with an average of the grants in adjacent years, as the 2006 grants include sizable debt relief. 
Figure 2. CEMAC Terms of Trade and Balance of Payments Developments, 19692008
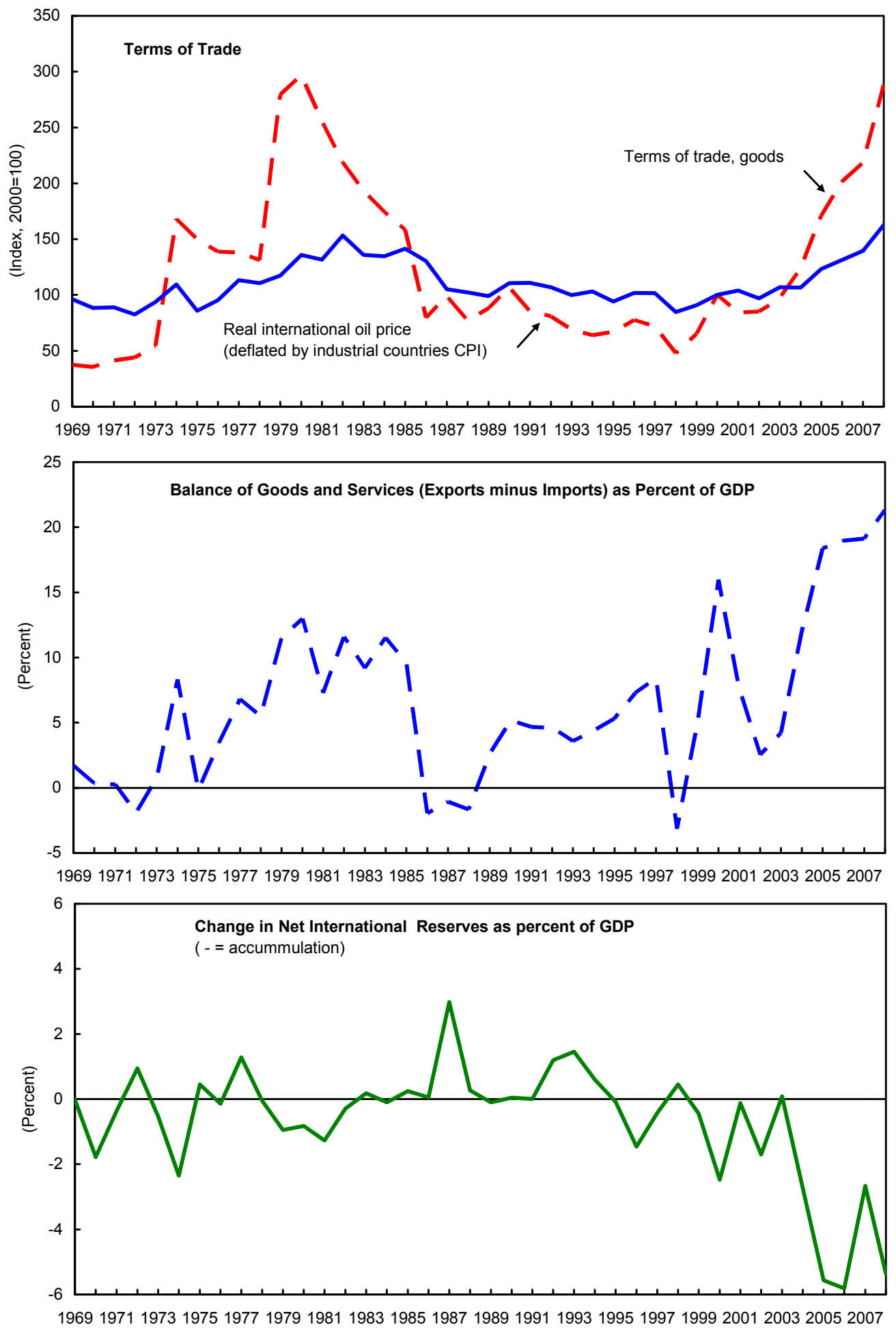

Sources: IMF's WEO database; national authorities; and IMF staff estimates.

Note: Presented ratios are constructed using CEMAC-wide aggregates of variables in the numerator and denominator. The CEMAC TOT index is a weighted average of CEMAC members' terms of trade indices, using as weights their shares in CEMAC's GDP in purchasing power parity US\$. 
According to traditional optimum currency area (OCA) criteria, CEMAC members do not seem well-positioned to benefit from a monetary union solely among themselves (Boughton, 1991; Bayoumi and Ostry, 1995; Hadjimichael and Galy, 1997; ECA, 2004a). In the Mundell I model (Box 2), the advantages of a currency union increase with the degree of integration of the goods and services, capital, and labor markets of prospective members, and with the degree of flexibility and diversification of their economies. CEMAC members, however, are in general undiversified commodity exporters with very little labor and capital mobility and minimal intraregional trade.

- $\quad$ A few export commodities account for a large share of CEMAC members' foreign exchange and fiscal receipts, and imports are dominated by finished investment and consumer goods that are mainly produced outside Africa (Bayoumi and Ostry, 1995). The production of tradables is generally not well-developed; to the extent it exists, it enjoys a degree of protectionism (Boughton, 1991) in the form of administrative hurdles, preferential tax treatment, or both. As a result, the share of intraregional in total external trade of members is minimal, accounting for roughly 2 percent of exports and 4 percent of imports (ECA, 2004a). ${ }^{2}$

- $\quad$ Capital markets are segmented and in their infancy and there is little formal labor mobility, though there are sizable groups of undocumented foreign workers in the more prosperous CEMAC members.

- The evidence for price and wage flexibility is mixed, with historic examples of the erosion of real wages in the run-up and immediate aftermath of the 1994 devaluation; past failures to keep producer prices of agricultural commodities in line with international prices (Boughton, 1991; ECA, 2004b); and the recent difficulties in some countries of reining in the public sector wage bill.

Nonetheless, the benefits of participation in the CFA franc zone become apparent when the fixed exchange rate peg to the euro is taken into account and modern approaches to the OCA debate are applied (Boughton, 1991; Bayoumi and Ostry, 1995; Hadjimichael and Galy, 1997). In the Mundell II model, the advantages of autonomous monetary and exchange rate policies are minimal compared with the benefits of pooling foreign reserves and importing prudent economic management by pegging the domestic currency to that of a dominant economic power.

- The considerably lower cumulative inflation in the CEMAC region relative to the rest of sub-Saharan Africa showcases the gains in macroeconomic stability derived from the fixed exchange rate.

\footnotetext{
${ }^{2}$ Intraregional trade is also limited by the lack of transportation infrastructure.
} 
- $\quad$ The large import component of CEMAC member consumer baskets is an argument in favor of pegging their currencies to that of their biggest trading partner because the high pass-through of nominal exchange rate fluctuations to domestic prices would limit their effect on the relative prices of tradables and nontradables and could undermine the stability and hence the liquidity value of a domestic currency (McKinnon, 1963). The European Union is the largest trading partner of CEMAC members, accounting for about 40 percent of their exports and 60 percent of their imports (ECA, 2004a).

- In the face of negative external shocks, the CEMAC's combined foreign reserves provide better coverage of the region's imports than what individual members affected by the shock can muster on their own, highlighting the benefits of risk sharing (i.e., pooling of reserves) (Figure 3). The benefits of reserve pooling are augmented by the fact that because CEMAC members are at different stages of economic development and depletion of nonrenewable resources, even when hit by a synchronized external shock they exhibit different patterns of foreign reserve accumulation and usage.

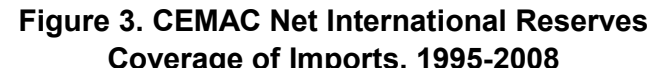
Coverage of Imports, 1995-2008

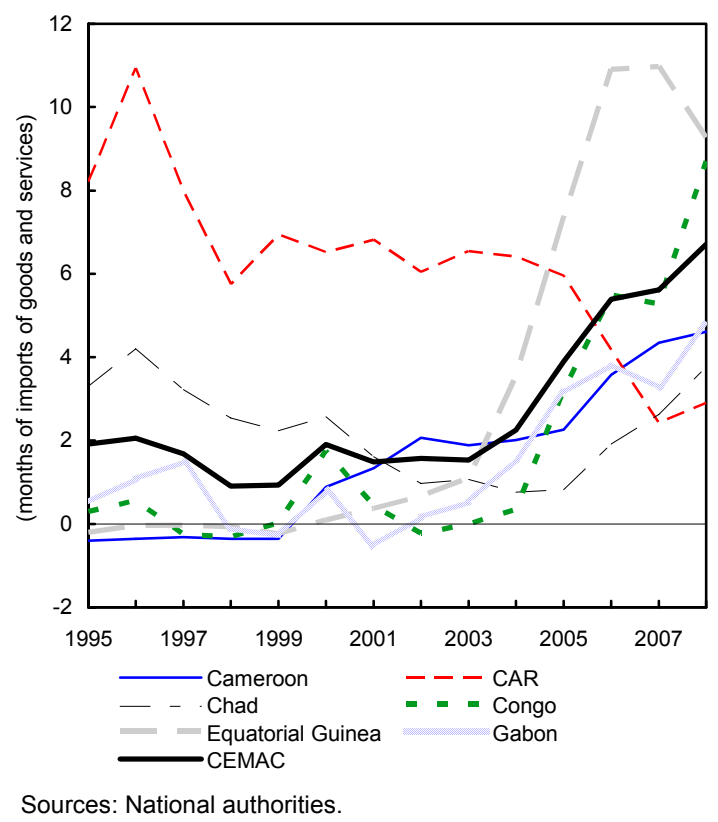

The revealed preference of the political establishments in member countries for monetary union suggests that the advantages of CEMAC membership exceed its opportunity costs. In other words, gains in regional stability and international standing, as well as the benefits of foreign reserve pooling and importing policy credibility via the peg to the euro exceed the costs of foregoing sovereignty over domestic currency issuance and hence monetary policy. This is true even though CEMAC members have yet to reap the potentially large benefits of closer intraregional integration. Structural reform and fiscal policies designed to unlock its full 
economic potential and the continued push for further political integration could bode well for the external viability of the union. ${ }^{3}$

\section{Box 2. Overview of the Optimum Currency Area Literature}

The optimum currency area (OCA) literature examines the conditions under which it is optimal for a country to join a monetary union and to opt for a fixed rather than flexible exchange rate regime (Bordo, 2003). The debate is cast in terms of the costs and benefits of exchange rate flexibility and of surrendering a country's sovereignty over domestic currency issuance and hence monetary policy (Tavlas, 1993).

The early insights from the OCA literature were premised on stationary expectations - which give rise to a downward-sloping Phillips curve — and flexible exchange rate models that emphasize its role in balancing the flows of international payments (McKinnon, 2004). Under these conditions, internal (full employment) and external (balance of payments) balance can be maintained in the face of exogenous supply and demand shocks by a mix of monetary and fiscal policies, to control domestic expenditure, and price flexibility (exchange rate or product and factor prices), to ensure the right product mix of tradables (exports and imports) and nontradables. In the Mundell I model (Mundell, 1961; McKinnon, 1963; Kenen, 1969), the decision on whether countries should form a monetary union depends on the incidence and severity of asymmetric terms of trade shocks on prospective members. These in turn depend on the degree of diversification and similarity of structures of their economies, and the flexibility and openness (compared to the other prospective members) of their goods and services, capital, and labor markets. The more open and flexible prospective members' economies and the more diversified and similar in structure they are, the stronger the case for a monetary union.

Modern approaches to the OCA debate rely on rational expectations - that give rise to a vertical Phillips curve and questions about the time consistency and credibility of policies - and models of flexible exchange rates that emphasize their role in equilibrating demand for and supply of domestic and foreign assets (Tavlas, 1993).

Under these conditions, the effectiveness of both exchange rate adjustments and monetary policy in systematically maintaining the internal and external balance of the economy is significantly diminished. In the Mundell II models (surveyed in Tavlas, 1993, and McKinnon, 2004), differences in economic structure, lack of diversification, and high terms of trade volatility increase the appeal of a monetary union because they increase the benefits of pooled foreign reserves and integrated capital markets. The latter function as an insurance policy upon which individual members can draw if there is an asymmetric shock. Furthermore, considerations of the consistency over time of policies highlight the benefits to countries with weak institutions of importing policy credibility by fixing their currency against that of a dominant economic power with a history of low inflation. Frankel and Rose (1998) have argued that countries' performance on the various OCA criteria is endogenous to joining a monetary union because the latter can stimulate closer integration.

Another aspect of the OCA literature examines the need for binding rules (convergence criteria) for monetary union members to preclude unsustainable fiscal policies. Proponents of such rules point to the extra incentives for opportunistic government behavior that membership creates. The opposing view is that the threat of rising debt risk premia and credit rationing, held by well functioning debt markets, will ensure fiscal discipline in MU members and non-members, alike. Only the opportunistic MU member will be saddled with a high sovereign risk premia, with no effect on the borrowing costs of other members. Therefore the only rule needed, is to prohibit the monetary financing of deficits, because it extracts a higher share of the joint seigniorage and lacks penalties in the form of debt risk premia. However, there is growing consensus in the OCA literature that convergence criteria can act as a commitment mechanism, if fiscal deficits are politically motivated (Buiter, Corsetti, and Roubini, 1993).

\footnotetext{
${ }^{3}$ The history of the CFA franc zone also shows that the primary reasons for its creation were political rather than economic (Maruping, 2005; Masson and Patillo, 2005).
} 


\section{A. Macroeconomic Policies in the CEMAC Region}

\section{Monetary policy}

Monetary policy in the CEMAC is subjugated to the objective of guaranteeing the stability of the CFA franc. The BEAC is entrusted with issuing the currency, formulating and conducting monetary and exchange rate policies, pooling and managing foreign exchange reserves (supported by a requirement that all export receipts be surrendered to the central bank), and keeping the region's payment systems functioning well. Monetary policy is formulated by a committee (MPC) that also manages the pooled foreign exchange reserves.

Under the 1972 Convention on Monetary Cooperation Between BEAC Member States and France, France guaranteed the convertibility of the CFA franc and since 1999 the Euro at a given parity. The signatories to this convention can change the parity after mutual consultation. In practice, CFA franc convertibility is ensured through an operations account at the French Treasury with an unlimited overdraft, through which the BEAC effectuates most of its international payments. The BEAC is obligated to place in this account up to 50 percent of its foreign assets, net of the counterpart in foreign assets of government deposits of over one year with the BEAC (i.e., Funds for Future Generations) and the BEAC reserve position at the IMF. Capital mobility is in principle free within the CEMAC and between the CEMAC and France, but in practice it is limited by administrative hurdles.

Given the overriding objective of exchange rate stability, BEAC has adopted two monetary targets: low inflation and maintaining an adequate foreign currency cover of the monetary base. For the region as a whole, the floor on net international reserve (NIR; BEAC foreign assets net of foreign liabilities of less than one year) coverage of the monetary base (BEAC sight liabilities) is set at 20 percent; its breach over three consecutive months triggers emergency measures (BEAC Statutes, Article 11). The BEAC also strives to keep the annual inflation rate in the region below 3 percent.

In monetary policy implementation, BEAC uses as instruments country-specific ceilings on BEAC government credits, quantitative targets on BEAC refinancing of commercial banks, and required reserve ratios. The BEAC Statutes limit (but do not prohibit) inflationary monetary financing of fiscal deficits of CEMAC members. ${ }^{4}$ In addition, the MPC sets country-specific required reserve ratios and quarterly targets on BEAC refinancing of commercial banks, in order to maintain the NIR coverage of base money in each CEMAC member within a desired range

\footnotetext{
${ }^{4}$ Traditionally, BEAC statutory advances to governments are capped at 20 percent of their last year's domestic ordinary fungible fiscal revenues. Drawings on statutory advances must be repaid within 12 months (BEAC Statutes, Art. 17 and 18). However, in June 2009, the MPC decided to freeze the ceilings on statutory advances at 20 percent of CEMAC members' 2008 domestic ordinary fungible fiscal revenue and to decrease them by 20 percent every year over 2010-15. Outstanding statutory advances in excess of the sliding ceilings must be repaid within 12 months.
} 
(between 75 and 100 percent in recent years). The consistency of the monetary policy instruments with BEAC monetary targets is ensured by the monetary programming exercise (Box 3). However, given the excess liquidity in the banking system, existing monetary policy instruments have not been effective in limiting money growth. This has forced the BEAC to rely in part on changes in the interest rates of its lending and deposit facilities to influence monetary outcomes. The continued use of country-specific monetary instruments reflects the reality that the product and factor markets of CEMAC members are not well integrated (Masson and Patillo, 2005).

\section{Box 3. BEAC Monetary Programming}

BEAC's monetary policy committee formulates policy and manages the pooled foreign exchange reserves. The MPC relies on a monetary programming exercise to set semi-annual targets on the net international reserves coverage of the monetary base and the growth rates of bank credit to the economy and broad money (M2) in each member state

The programming exercise is based on real sector projections from the supply side of national accounts, which drive the outlook for the balance of payments. These are combined to form an estimate of the expected change in net foreign assets of the central bank and commercial banks. The growth of broad money is assumed to follow the nominal GDP projection with constant velocity. The aggregate money projection is then broken down into currency in circulation and sight and term deposits using historic patterns. The change in net domestic assets is obtained from the monetary survey identity $(\Delta \mathrm{M}=\Delta \mathrm{NFA}$ $+\triangle \mathrm{NDA})$; the projected changes in net domestic assets, derived from fiscal budgets and their mid-year execution, are used to set targets for government use of statutory advances from the BEAC; the change in banking sector domestic credit to the rest of the economy $\left(\triangle D C^{\mathrm{P}}\right)$ is then obtained as a residual from the monetary survey identity $\left(\Delta N D A=\Delta \mathrm{NDA}^{\mathrm{G}}+\Delta \mathrm{NDA}^{\mathrm{P}}\right)$ and used to set targets on BEAC refinancing of commercial banks.

\section{Fiscal policy}

Fiscal policies and public debt management are prerogatives of national governments. All six CEMAC members are exporters of nonrenewable resources (oil and diamonds) and primary commodities (logs and timber) at different stages of development and depletion of their resource endowments. The budgets of the oil exporters - Cameroon, Chad, Congo, Equatorial Guinea, and Gabon - are heavily influenced by oil revenue, which has characteristics similar to foreign grants, in that they should be considered transitory in formulating government policies for both the short- and long-term (Box 4). Their budget balances swing widely with the volatility in world oil (and commodity and mineral) prices (Figure 4), which create challenges for the smooth execution and planning of the budget. Several consequences follow from this: large swings in fiscal policy tend to be destabilizing, fiscal policies across CEMAC tend to have a procyclical bias, and focusing on the fiscal balance will give a misleading view of the fiscal stance. Due to the stickiness of government spending, downturns in world oil prices have in the past also resulted in excessive government indebtedness to foreign investors, domestic banks, and suppliers. Moreover, government spending financed by oil revenue is inherently unsustainable in the long run because nonrenewable natural resources are exhaustible. The budget of the C.A.R. exhibits similar dynamics, with diamonds and external grants assuming the role of oil. 


\section{Box 4. Characteristics of Oil Revenue in the CEMAC}

The characteristics of CEMAC oil producers are that (i) oil extraction is carried out mainly by foreign companies with access to international banks and credit markets and is primarily financed externally; (ii) oil extraction has significant upfront fixed costs, so that production-sharing contracts between oil companies and national governments tend to be long-term; (iii) linkages between the foreign-operated oil and the domestic non-oil sectors are minimal — production is highly capital-intensive, the small labor force is dominated by expatriates, and the capital goods and services used are highly specialized and are predominantly imported; (iv) the price of oil on international markets, which is quoted in US\$, has historically been highly volatile, which makes accurate revenue forecasts difficult; and (v) the government take in oil revenue is received primarily in foreign currency, and the share of oil valueadded that does not accrue to the government is mostly expatriated to the foreign parent companies.

As a consequence, in CEMAC oil producers, government oil revenue has an impact on the balance of payments and the government budget similar to that of foreign grants.

- On the external side, government oil revenue could be considered as a transitory or exogenous source of financing of the current account balance of the non-oil sector.

- On the budget side government oil revenue could be considered as transitory or exogenously determined (by contractual terms, world oil prices, and exchange rates), and if not collected by the government the freed-up value-added will not remain in the domestic economy and will not lead to a change in domestic demand.

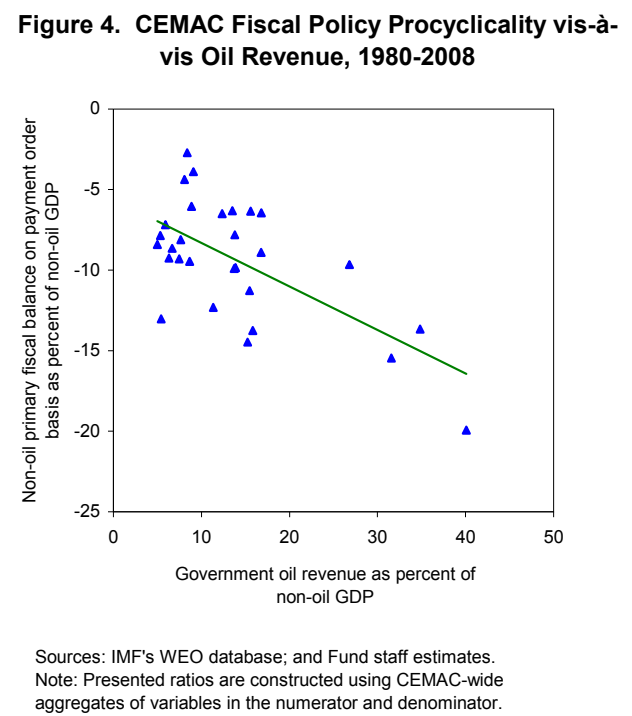

\section{B. Policy Coordination and Surveillance}

The need for fiscal and monetary policy coordination in the CEMAC arises from the possibility of monetary financing of fiscal deficits, and the impact of fiscal policies on the region's competitiveness. From a theoretical point of view, the findings of the OCA literature highlight the need for fiscal rules for monetary union members when fiscal policies follow political cycles and are not subject to the discipline imposed by sound debt markets (see Box 2 above). Moreover, under the fixed exchange rate regime of a common currency, the impact of expansionary fiscal policies on domestic prices is a concern because of the potential for an overvaluation of the real effective exchange rate (REER) in the long run. 
Recognizing the need to coordinate fiscal and monetary policy, in 1994 CEMAC members adopted a regional surveillance framework. The overriding objective of surveillance, which is conducted by the CEMAC Commission, is to prevent the occurrence of excessive fiscal deficits. A budget deficit is deemed excessive if it, and, in particular its financing, is incompatible with the objectives of monetary policy, such as the NIR coverage of base money (Article 55). In 2001 the CEMAC refined the framework by adopting quantitative convergence criteria, with most of which members were to comply by the end 2007 (the inflation criterion entered into force immediately, see Box 5).

The four main convergence criteria are complemented by three "adjusted criteria" that aim to better capture policy efforts toward convergence by removing the effect of exogenous factors. Countries not in compliance with the four main criteria are required to adopt three-year adjustment programs to achieve convergence. However, this requirement has not been enforced in practice and there are no sanctions for noncompliance.

The adoption in 2008 of a new supplementary criterion on the non-oil basic fiscal balance is an important step in improving regional surveillance. As shown in the previous sections, targeting a measure of fiscal deficits that abstracts from the volatile and temporary oil revenue could improve the sustainability of fiscal policies and the CFA franc peg. However, such a measure should ideally exclude from its definition net interest payments and its target should be countryspecific.

\section{Box 5. CEMAC Convergence Criteria}

The four main surveillance criteria adopted by the CEMAC in 2001 are:

- Basic fiscal balance as percent of nominal GDP $\geq 0$ percent: The basic fiscal balance is equal to the difference between total revenue net of grants and total expenditure net of foreign-financed capital spending. In the 2008 evaluation of the progress made toward convergence, the CEMAC Commission used two supplementary criteria: (i) basic structural fiscal balance as percent of nominal GDP $\geq 0$ percent - derived from the main criterion by replacing actual oil revenue with the three-year moving average; and (ii) the non-oil basic fiscal balance in percent of non-oil GDP $\geq 0$.

- Average annual inflation $\leq \mathbf{3}$ percent: This criterion is complemented by the adjusted indicator of the average annual underlying inflation $\leq 3$ percent, which is obtained by stripping the overall CPI index of its most volatile component, the food sub index.

- Stock of domestic and external debt as percent of nominal GDP $\leq 70$ percent.

- Non-accumulation of domestic and external payment arrears.

In the 2008 evaluation of progress made toward convergence, the CEMAC Commission used the following secondary surveillance criteria, compliance with which is not obligatory:

- Ratio of net international reserves to monetary base $\geq 20$ percent.

- Primary fiscal balance as percent of nominal GDP $\geq 0$ percent.

- $\quad$ Non-oil fiscal revenue in percent of nominal GDP $\geq 17$ percent.

- Ratio between the change in the public wage bill and the change in revenues $\leq 1$ percent.

- Current account balance net of grants as percent of nominal GDP $\geq 0$ percent. 


\section{Improving The Measures OF Fiscal SURVEILlanCe}

\section{A. Fiscal Policy Objectives and Indicators}

A government's fiscal policy reflects a mix of objectives, among them control of aggregate demand, stabilization of public debt, and improvement of economic efficiency. Fiscal policy affects these objectives differently and to assess its impact a range of fiscal indicators is essential. Any single indicator - or criterion - is unlikely to give a comprehensive description of the impact of policy on the relevant objective. As noted by Blanchard (1990) there are several aspects of fiscal policy for which indicators would be useful:

- $\quad$ Policy changes: To account for changes in the fiscal position (spending, taxes, transfers) due to discretionary changes in policy, rather than due to the economic environment.

- Sustainability: To assess whether the current fiscal position can be sustained without exploding public debt.

- Impact on aggregate demand: To determine how the fiscal position would affect aggregate demand in the short and medium term - in other words, to assess whether fiscal policy is acting as catalyst or restraint on domestic saving and investment.

- Microeconomic efficiency: To assess the impact of the tax and/or incentive structure on aggregate supply, saving and investment, and the labor market.

Given these different aspects of fiscal policy, there must be a trade-off in selecting appropriate fiscal indicators between economic arguments on the one hand and ease of estimation and understanding on the other. Consequently, in establishing criteria against which fiscal policy indicators could be judged, it is desirable to have a few guiding principles in mind. To be effective, indicators should therefore be based on

- $\quad$ the simplest formulation as possible consistent with the measurement objective, which would facilitate their calculation and interpretation;

- $\quad$ positive rather than normative economic principles, leaving it to the user to make judgments about the broader economic environment in a particular country;

- $\quad$ similar definitions and concepts when used for cross-country comparisons; and

- $\quad$ as few projections as feasible.

In this section we consider a range of fiscal indicators, as well as the existing convergence criteria, with a view to (i) clarifying the picture of fiscal developments in the CEMAC region, and (ii) improving fiscal policy surveillance and analysis. We restrict our attention to the indicators monitoring changes in fiscal policy and fiscal sustainability, the two areas emphasized 
by the CEMAC convergence criteria. We first try to interpret recent fiscal developments in the context of CEMAC's convergence criteria, which prove difficult when world oil prices are relatively high. We then consider the usefulness of a measure of the fiscal stance and fiscal impulse in assessing policy changes and of two measures that could help shed light on sustainability. We have narrowed the range of fiscal indicators to these, bearing in mind the principles of a good indicator and the questions at hand. ${ }^{5}$

\section{B. Indicators of Policy Stance and Policy Change}

\section{CEMAC convergence criteria}

It has long been recognized that CEMAC's convergence criteria may not provide an appropriate framework for fiscal policy surveillance, although the recent adoption of the non-oil basic fiscal balance as an additional criteria is a step in the right direction (see Box 5). The reason seems straightforward: with five of the six CEMAC members being oil producers, volatility in world oil prices and production could easily mask changes in fiscal policy. In an environment of oilrelated surpluses in recent years, the traditional fiscal convergence criteria (basic fiscal balance, defined as the difference between total revenue, less grants, and total expenditure, less foreignfinanced outlays) and the complementary adjustment criteria (basic structural fiscal balance and, for oil producers the non-oil basic fiscal balance) could be giving a misleading signal of the "true" fiscal stance. For example, a temporary increase in oil-related revenue can lead to an expansionary fiscal policy that would not raise any alarms, from the regional surveillance standpoint, if the increase in spending is smaller than the increase in revenue, even if this increased spending is not sustainable. While the introduction of the non-oil basic fiscal balance as an adjustment criterion does offer some improvement, the target $(\geq 0)$ must take into account country-specific considerations concerning long-term fiscal sustainability and the factors that influence it, in order to be relevant and effective.

The difficulty in assessing CEMAC countries' fiscal policy based on the existing convergence criteria has become increasingly evident with wide swings in world oil prices in recent years. The weakness in world prices in the latter part of the 1990s and the run-up in prices since early in this decade (Figure 5) had a profound, but perhaps predictable, impact on the fiscal position of all CEMAC countries, including the C.A.R., which does not produce oil. Table 1 shows that the fiscal convergence criteria was missed by all or a majority of countries in 1998-2000, but only

\footnotetext{
${ }^{5}$ Many different indicators could be used to assess the fiscal position and answer other broad questions about fiscal policy. Jacobs (2002), for example, estimates 30 different measures of the budget balance for South Africa based on different definitions of the current balance (measuring government savings); the primary balance (which excludes interest payments); public debt/GDP ratio and the primary tax gaps (measuring fiscal sustainability); and the public sector borrowing requirement. These indicators could also be supplemented with measures of fiscal impact and discretion, including cyclically-adjusted balances. While these indicators are interesting in their own right, such a comprehensive set is not necessary in the context of surveillance, where interest may be narrowly focused on the general direction and thrust of fiscal policies.
} 
C.A.R., which did not directly benefit from the recent oil price hikes, has experienced a deficit since 2004 (when Chad joined the ranks of oil producers). Compared with the basic fiscal balance criteria, the over-performance was substantial, ranging from a basic fiscal surplus of 33.6 percent of GDP for Congo to $1 \frac{1}{2}$ percent of GDP for Cameroon. Moreover, the fiscal surpluses as defined by the convergence criteria are misleading because (i) they masked very expansionary fiscal policy in the short term and (ii) they did not address the medium-term sustainability issues in oil producing countries (both discussed below).

A similar picture emerges for the adjustment criterion on the basic structural fiscal balance, defined similarly to the basic balance but replacing current oil revenue by its three-year moving average. Except for Chad and the C.A.R., all countries have observed this criterion because of high world oil prices over a relatively long period. In contrast, none of the oil producers met the new adjustment criterion on the non-oil basic fiscal balance over the past decade.

Figure 5. Nominal and Real Crude Oil (Spot) Prices, 1970-2014 (in US Dollars) ${ }^{1}$

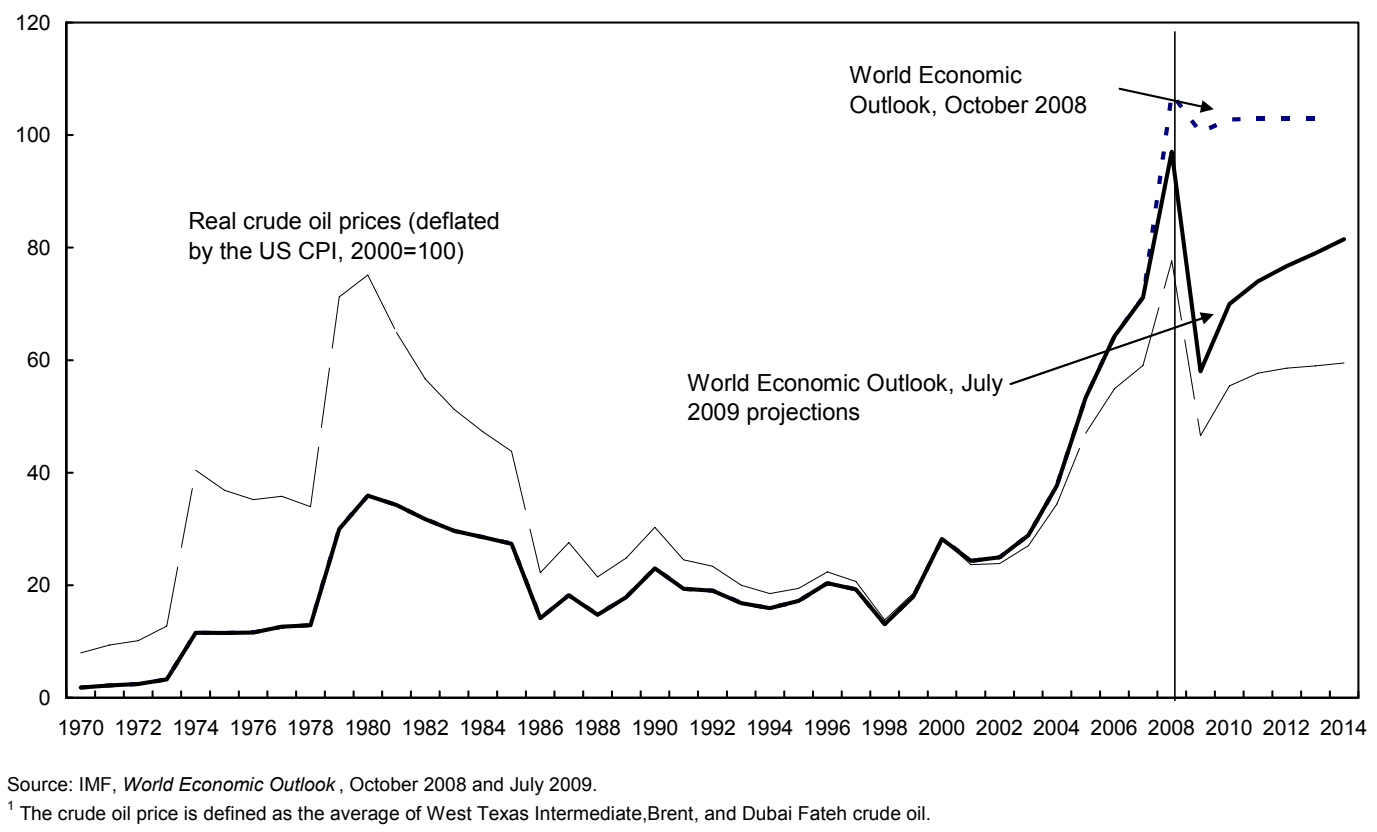


Table 1. CEMAC Fiscal Developments and the Fiscal Convergence Criteria, 1998-2008 (in units indicated) ${ }^{1}$

\begin{tabular}{|c|c|c|c|c|c|c|c|c|c|c|c|}
\hline & 1998 & 1999 & 2000 & 2001 & 2002 & 2003 & 2004 & 2005 & 2006 & 2007 & 2008 \\
\hline & \multicolumn{11}{|c|}{ Basic fiscal balance in percent of nominal GDP $\geq 0^{2}$} \\
\hline Cameroon & -2.4 & -1.0 & 2.0 & 3.3 & 0.8 & 1.1 & 0.0 & 3.5 & 5.4 & 3.9 & 1.5 \\
\hline Central African Republic & -8.7 & -8.6 & -6.5 & -4.1 & -4.2 & -4.4 & -5.2 & -8.2 & -4.0 & -2.5 & -3.0 \\
\hline Chad & -0.4 & -2.0 & -3.1 & -2.4 & -3.2 & -3.4 & -0.2 & 1.1 & 3.8 & 4.3 & 5.0 \\
\hline Congo, Republic of & -19.9 & -5.8 & 1.5 & 6.4 & 0.5 & 1.0 & 4.6 & 15.9 & 17.1 & 11.1 & 26.8 \\
\hline Equatorial Guinea & -7.7 & -0.2 & -2.5 & 14.4 & 16.9 & 11.8 & 12.3 & 20.6 & 23.5 & 17.8 & 15.3 \\
\hline \multirow[t]{2}{*}{ Gabon } & -1.3 & 4.3 & 13.9 & 7.7 & 6.8 & 10.8 & 8.0 & 9.6 & 10.2 & 9.4 & 12.2 \\
\hline & \multicolumn{11}{|c|}{ Adjustment criteria I: Basic structural fiscal balance in percent of nominal GDP $\geq 0^{3}$} \\
\hline Cameroon & -1.6 & -2.7 & -0.1 & 3.7 & 1.0 & 1.4 & 0.2 & 2.7 & 3.5 & 3.3 & 0.4 \\
\hline Central African Republic & -9.4 & -9.6 & -6.8 & -4.4 & -5.7 & -2.6 & -4.2 & -8.6 & -5.4 & -3.9 & -4.0 \\
\hline Chad & -0.4 & -2.0 & -3.1 & -2.4 & -3.2 & -3.4 & -2.1 & -1.3 & -2.2 & -1.4 & -0.2 \\
\hline Congo, Republic of & -13.1 & -8.5 & -6.1 & 4.5 & 2.2 & 0.8 & 1.4 & 4.6 & 4.6 & 11.0 & 17.0 \\
\hline Equatorial Guinea & -14.7 & -3.5 & -8.6 & 4.5 & 11.2 & 8.5 & 3.5 & 8.2 & 12.5 & 13.3 & 8.1 \\
\hline \multirow[t]{2}{*}{ Gabon } & 16.0 & 10.5 & 5.9 & 11.5 & 16.2 & 13.2 & 11.3 & 26.9 & 28.4 & 29.5 & 28.1 \\
\hline & \multicolumn{11}{|c|}{ Adjustment criteria II: Basic non-oil basic fiscal balance in percent of non-oil GDP $\geq 0$} \\
\hline Cameroon & -4.7 & -6.3 & -5.2 & -1.6 & -4.3 & -3.1 & -4.1 & -1.6 & -1.6 & -2.7 & -7.1 \\
\hline Central African Republic & $\ldots$ & $\ldots$ & $\ldots$ & $\ldots$ & $\ldots$ & $\ldots$ & $\ldots$ & $\ldots$ & $\ldots$ & $\ldots$ & $\ldots$ \\
\hline Chad & -0.4 & -2.0 & -3.1 & -2.4 & -3.3 & -3.9 & -5.1 & -6.7 & -15.8 & -22.7 & -29.0 \\
\hline Congo, Republic of & -50.3 & -53.2 & -54.7 & -33.6 & -39.5 & -39.4 & -39.1 & -44.2 & -66.1 & -62.9 & -53.3 \\
\hline Equatorial Guinea & -73.5 & -52.6 & -85.1 & -35.6 & -24.1 & -47.7 & -68.5 & -63.9 & -66.1 & -61.4 & -75.7 \\
\hline Gabon & -28.1 & -13.9 & -16.8 & -24.3 & -18.5 & -9.9 & -15.4 & -21.3 & -20.8 & -15.8 & -17.9 \\
\hline
\end{tabular}

\section{Fiscal stance and fiscal impulse}

To improve fiscal surveillance in the CEMAC context we consider a measure of the fiscal stance and fiscal impulse that the IMF has used for its multilateral surveillance for the past several decades. The rationale is that the actual budget balance may be a misleading indicator of the thrust of policy because it is not clear whether changes in it are the cause or the result of economic activity. Ideally, we would want an indicator to help distinguish between certain cyclical factors that may have a temporary effect on the actual budget balance and the effects of changes in the fiscal position due to policy or structural changes that may have more lasting impact. ${ }^{6}$ Reflecting this need, the fiscal stance and fiscal impulse indicators attempt to measure the total stimulus to aggregate demand arising from fiscal policy from whatever source, whether discretionary or otherwise, during a given period (Heller et al, 1986). ${ }^{7}$ They capture any change in the actual budget balance that is not transitory in a cyclical sense.

\footnotetext{
${ }^{6}$ In passing, we should also note that increased spending financed by a permanent increase in oil revenue would constitute a positive fiscal impulse.

${ }^{7}$ Further details on the methodology, construction, and criticisms of the IMF's fiscal impulse measure can be found in Chand (1992) and Schinasi and Lutz (1991). A different formulation of the fiscal impulse focuses on separating endogenous and exogenous elements of the actual budget balance, with a view to measuring discretionary changes in fiscal policy, compared with its thrust. This second formulation is used, for example, by the OECD.
} 
Conceptually, the fiscal stance is the deviation of the actual budget balance from a "cyclically neutral budget balance", which is derived by (i) choosing a reference year in which actual and potential output are judged to be relatively similar; and (ii) projecting revenue and expenditure in the current year based on the assumption of unitary elasticities of revenue and expenditure with regard to actual and potential GDP, so as to account for the contribution to the fiscal stimulus of discretionary actions and the automatic stabilizers. The fiscal impulse is simply the change in the fiscal stance from the previous year, which reflects the change in the government budget balance resulting only from changes in government expenditure and/or tax policies (Box 6). The fiscal impulse indicator is useful for at least two purposes: (i) for monitoring the performance of fiscal authorities and (ii) for international comparisons of fiscal policy changes (Schinasi and Lutz, 1991).

\section{Box 6. Fiscal Stance and Fiscal Impulse}

Following Heller et al (1986), we can decompose the actual budget balance $(B=T-G)$ into three components: the base year surplus, the cyclical element, and the fiscal stance:

$$
\mathrm{B}=\left(\mathrm{t}_{0} \mathrm{Y}^{\mathrm{p}}-\mathrm{g}_{0} \mathrm{Y}^{\mathrm{p}}\right)-\left(\mathrm{t}_{0}\left(\mathrm{Y}^{\mathrm{p}}-\mathrm{Y}\right)\right)-\mathrm{FIS}
$$

where $T$ is government revenue, $G$ is government expenditure, $t_{0}$ is the revenue ratio in the base period, $\mathrm{Y}^{\mathrm{p}}$ is potential nominal output, $\mathrm{g}_{0}$ is the base-year ratio of government expenditure, $\mathrm{Y}$ is actual nominal output, and FIS is a measure of the fiscal stance. In equation (1), an actual deficit in excess of the cyclically neutral deficit (first two terms) is considered expansionary, relative to the base year fiscal stance, and the fiscal stance measure (FIS) is positive. We can combine the first two terms in equation (1) to form the cyclically neutral budget balance $\left(\mathrm{B}^{\mathrm{n}}\right)$ and reformulate the expression as

$$
\mathrm{B}=\left(\mathrm{t}_{0} \mathrm{Y}-\mathrm{g}_{0} \mathrm{Y}^{\mathrm{p}}\right)-\mathrm{FIS}=\mathrm{B}^{\mathrm{n}}-\mathrm{FIS}
$$

Taking the first difference of the fiscal stance measure FIS gives the indicator of the fiscal impulse in equation (3)

$$
\mathrm{FI}=\left(\Delta \mathrm{G}-\mathrm{g}_{0} \Delta \mathrm{Y}^{\mathrm{p}}\right)-\left(\Delta \mathrm{T}-\mathrm{t}_{0} \Delta \mathrm{Y}\right)
$$

Since interest rates are not generally under the direct control of fiscal authorities, we have further refined our analysis to focus on the primary fiscal balance; consequently, budgetary changes due to movements in debt payments should not be viewed as discretionary or imparting a fiscal thrust. For comparability between countries, we have calculated the fiscal stance and fiscal impulse measures based on a common base year (2001) and estimated potential output using a Hodrick-Prescott filter with historical data and projections over 1965-2014. These assumptions could, of course, be refined to reflect country-specific factors and more sophisticated modeling strategies (in particular, for potential output), although we believe a parsimonious approach is sufficient to shed light on the issues we are interested in exposing.

The measure of the fiscal stance suggests that the general thrust of fiscal policies in three of the six CEMAC member countries has been expansionary so far this decade (Table 2). This is a somewhat different message than provided by the overall balance (the region's primary fiscal indicator) alone, which shows fiscal surpluses in all oil-producing countries. Measured by the fiscal stance, fiscal policy in the C.A.R. and more recently in Chad and Congo has been 
contractionary. For C.A.R. this probably reflects its difficult financial environment and reduced resource envelope; for Chad and Congo, increased oil production widened primary surpluses. For the C.A.R., Chad, and Congo, the point is further stressed by their contractionary (negative) fiscal impulse through most of the latter part of the period. The fiscal stance indicator suggest that the CEMAC region as a whole had roughly a neutral fiscal balance after cyclical adjustments in 2008, with a negative fiscal impulse indicating some policy tightening since 2007. We would argue, however, that the apparent fiscal tightening in CEMAC oil-producing countries was misleading and largely caused by booming oil revenue (see below).

\section{Fiscal stance and fiscal impulse, excluding oil revenue}

Following Barnett and Ossowski (2003) we also suggest that oil-producing CEMAC member countries should put more surveillance emphasis on the non-oil primary balance for a number of reasons: (i) in the management of oil resources, oil wealth defined by the present discounted value of future oil revenue is the key variable of interest, so fiscal proceeds from oil should be viewed as financing rather than income; (ii) the overall balance and the primary balance (including oil) are affected by oil price volatility, which is outside the control of the fiscal authorities, and movements in these indicators from changes in oil revenue do not directly affect domestic demand; (iii) it provides a measure of fiscal vulnerability and sustainability; and (iv) it is a better measure of the fiscal impulse consistent with the medium-term sustainability.

The measure of the fiscal stance excluding oil revenue presents an even more expansionary picture (Table 3). When oil revenue is stripped from the calculation, the thrust of fiscal policies in all of the oil producers seem strongly expansionary over 2005-08 (indeed over 2000-08 except for Gabon), including Chad and Congo, whose fiscal stances were misjudged to be contractionary if oil revenue were included (see the preceding section). Consistent with the assessment for individual countries, the CEMAC members as a group have consistently pursued expansionary fiscal policies since the beginning of this decade and the degree of expansion has steadily increased over the last five years. Consequently, relying on the convergence criteria (basic fiscal balance), or fiscal stance and fiscal impulse (including oil revenue) alone could provide a misleading signal about the direction of fiscal policies. When world oil prices peaked in 2008, only Congo started to reverse its fiscal stance as indicated by a negative fiscal impulse in Table 3.

The measure of the non-oil fiscal impulse also demonstrates the pro-cyclical nature of fiscal policies across most of the CEMAC countries. The estimated fiscal impulses are shown in Figure 6 , along with the growth of non-oil real GDP. This juxtaposition is highly revealing; the fiscal impulse moves more or less in line with the growth rate.

While the fiscal stance and fiscal impulse are quantitatively easy to calculate, they are not free from criticism. Some authors question the justification for an indicator that is not model-based (see Blanchard, 1990, and Buiter, 1983) and ask why actual growth in government expenditure should be tested against potential output while actual growth in revenue is tested against actual 
output. In response, some authors have tried to provide a theoretical or model-based foundation for the fiscal impulse measure and suggested other technical improvements (see, e.g., Heller et al., 1986; Schniasi and Lutz, 1991; and Chand, 1992).

Table 2. A Comparison of CEMAC Fiscal Indicators, 2000-08 (in percent of GDP) ${ }^{1}$

\begin{tabular}{|c|c|c|c|c|c|c|c|c|c|}
\hline & 2000 & 2001 & 2002 & 2003 & 2004 & 2005 & 2006 & 2007 & 2008 \\
\hline \multicolumn{10}{|l|}{ Cameroon } \\
\hline Basic fiscal balance & 2.0 & 3.3 & 0.8 & 1.1 & 0.0 & 3.5 & 5.4 & 3.9 & 1.5 \\
\hline Primary balance & 5.8 & 6.3 & 3.5 & 3.4 & 2.0 & 5.0 & 6.3 & 4.4 & 1.8 \\
\hline Primary fiscal stance & 0.4 & 0.0 & 2.8 & 2.9 & 4.3 & 1.1 & -0.2 & 1.6 & 4.2 \\
\hline Primary fiscal impulse & -2.2 & -0.4 & 2.8 & 0.1 & 1.4 & -3.2 & -1.4 & 1.9 & 2.6 \\
\hline \multicolumn{10}{|l|}{ Central African Republic } \\
\hline Basic fiscal balance & -6.5 & -4.1 & -4.2 & -4.4 & -5.2 & -8.2 & -4.0 & -2.5 & -3.0 \\
\hline Primary balance & -4.8 & -2.7 & -2.6 & -3.2 & -4.0 & -7.3 & -3.1 & -1.4 & -1.1 \\
\hline Primary fiscal stance & 2.2 & 0.0 & -0.3 & -0.9 & -0.2 & 3.1 & -0.9 & -2.6 & -3.7 \\
\hline Primary fiscal impulse & -2.3 & -2.2 & -0.3 & -0.6 & 0.7 & 3.4 & -4.1 & -1.6 & -1.1 \\
\hline \multicolumn{10}{|l|}{ Chad } \\
\hline Basic fiscal balance & -3.1 & -2.4 & -3.2 & -3.4 & -0.2 & 1.1 & 3.8 & 4.3 & 5.0 \\
\hline Primary balance & -2.0 & -1.6 & -2.3 & -2.8 & 0.2 & 1.4 & 4.3 & 4.7 & 5.3 \\
\hline Primary fiscal stance & 0.1 & 0.0 & 0.7 & 1.7 & 0.4 & -0.8 & -4.0 & -4.8 & -5.7 \\
\hline Primary fiscal impulse & 0.2 & -0.1 & 0.7 & 1.0 & -1.3 & -1.1 & -3.2 & -0.8 & -0.9 \\
\hline \multicolumn{10}{|l|}{ Congo, Republic of } \\
\hline Basic fiscal balance & 1.5 & 6.4 & 0.5 & 1.0 & 4.6 & 15.9 & 17.1 & 11.1 & 26.8 \\
\hline Primary balance & 8.4 & 6.8 & 1.2 & 6.8 & 9.8 & 20.8 & 21.5 & 13.9 & 29.9 \\
\hline Primary fiscal stance & -1.7 & 0.0 & 5.8 & -0.5 & -3.7 & -13.9 & -14.3 & -8.1 & -24.0 \\
\hline Primary fiscal impulse & -1.5 & 1.7 & 5.8 & -6.3 & -3.2 & -10.2 & -0.3 & 6.1 & -15.9 \\
\hline \multicolumn{10}{|l|}{ Equatorial Guinea } \\
\hline Basic fiscal balance & -2.5 & 14.4 & 16.9 & 11.8 & 12.3 & 20.6 & 23.5 & 17.8 & 15.3 \\
\hline Primary balance & -2.1 & 14.9 & 17.2 & 11.9 & 12.3 & 20.7 & 23.5 & 17.9 & 15.3 \\
\hline Primary fiscal stance & 13.3 & 0.0 & -2.5 & 2.2 & 3.9 & -4.8 & -8.6 & -1.6 & 1.4 \\
\hline Primary fiscal impulse & 1.5 & -13.3 & -2.5 & 4.7 & 1.7 & -8.7 & -3.9 & 7.0 & 3.0 \\
\hline \multicolumn{10}{|l|}{ Gabon } \\
\hline Basic fiscal balance & 13.9 & 7.7 & 6.8 & 10.8 & 8.0 & 9.6 & 10.2 & 9.4 & 12.2 \\
\hline Primary balance & 19.8 & 16.5 & 11.2 & 14.8 & 12.0 & 12.4 & 12.5 & 11.5 & 14.0 \\
\hline Primary fiscal stance & -3.5 & 0.0 & 5.1 & 1.7 & 4.4 & 4.2 & 4.0 & 5.6 & 3.1 \\
\hline Primary fiscal impulse & -9.1 & 3.5 & 5.1 & -3.4 & 2.8 & -0.2 & -0.3 & 1.6 & -2.5 \\
\hline \multicolumn{10}{|l|}{ CEMAC } \\
\hline Basic fiscal balance & 4.8 & 3.8 & 2.0 & 3.2 & 2.8 & 5.7 & 7.5 & 4.9 & 6.9 \\
\hline Primary balance & 9.1 & 7.3 & 4.4 & 5.8 & 5.1 & 7.5 & 9.0 & 5.9 & 7.9 \\
\hline Primary fiscal stance & -2.3 & 0.0 & 2.8 & 1.3 & 2.6 & 0.2 & -1.6 & 1.7 & -0.2 \\
\hline Primary fiscal impulse & -4.1 & 2.3 & 2.8 & -1.5 & 1.3 & -2.4 & -1.8 & 3.2 & -1.9 \\
\hline
\end{tabular}

Source: Country authorities; and IMF staff estimates and projections.

${ }^{1}$ The basic fiscal balance is defined according to the convergence criteria; primary balance is equal to the sum of basic fiscal balance and interest payments; The primary fiscal stance and primary fiscal impulse are described in details in the text. 
Table 3. A Comparison of CEMAC Fiscal Indicators, 2000-08 (in percent of non-oil GDP) ${ }^{1}$

\begin{tabular}{|c|c|c|c|c|c|c|c|c|c|}
\hline & 2000 & 2001 & 2002 & 2003 & 2004 & 2005 & 2006 & 2007 & 2008 \\
\hline \multicolumn{10}{|l|}{ Cameroon } \\
\hline Non-oil basic fiscal balance & -5.2 & -1.6 & -4.3 & -3.1 & -4.1 & -1.6 & -1.6 & -2.7 & -7.1 \\
\hline Non-oil primary balance & -0.9 & 1.6 & -1.5 & -0.7 & -2.0 & 0.0 & -0.6 & -2.2 & -6.7 \\
\hline Non-oil primary fiscal stance & 2.4 & 0.0 & 3.2 & 2.4 & 3.8 & 1.7 & 2.1 & 3.6 & 8.2 \\
\hline Non-oil primary fiscal impulse & -0.8 & -2.4 & 3.2 & -0.7 & 1.4 & -2.2 & 0.4 & 1.6 & 4.6 \\
\hline \multicolumn{10}{|l|}{ Chad } \\
\hline Non-oil basic fiscal balance & -3.1 & -2.4 & -3.3 & -3.9 & -5.1 & -6.7 & -15.8 & -22.7 & -29.0 \\
\hline Non-oil primary balance & -2.0 & -1.7 & -2.4 & -3.2 & -4.3 & -6.0 & -15.0 & -22.0 & -28.4 \\
\hline Non-oil primary fiscal stance & -0.1 & 0.0 & 0.9 & 1.9 & 2.7 & 4.9 & 13.8 & 20.7 & 27.1 \\
\hline Non-oil primary fiscal impulse & 0.5 & 0.1 & 0.9 & 0.9 & 0.8 & 2.2 & 8.9 & 6.9 & 6.3 \\
\hline \multicolumn{10}{|l|}{ Congo, Republic of } \\
\hline Non-oil basic fiscal balance & -54.7 & -33.6 & -39.5 & -39.4 & -39.1 & -44.2 & -66.1 & -62.9 & -53.3 \\
\hline Non-oil primary balance & -34.6 & -32.8 & -38.0 & -27.8 & -27.1 & -30.5 & -52.0 & -55.7 & -43.7 \\
\hline Non-oil primary fiscal stance & -2.6 & 0.0 & 7.0 & -3.2 & -4.3 & -1.2 & 20.2 & 24.1 & 11.7 \\
\hline Non-oil primary fiscal impulse & 13.2 & 2.6 & 7.0 & -10.2 & -1.2 & 3.1 & 21.4 & 3.9 & -12.4 \\
\hline \multicolumn{10}{|l|}{ Equatorial Guinea } \\
\hline Non-oil basic fiscal balance & -85.1 & -35.6 & -24.1 & -47.7 & -68.5 & -63.9 & -66.1 & -61.4 & -75.7 \\
\hline Non-oil primary balance & -83.1 & -33.2 & -23.0 & -47.3 & -68.2 & -63.7 & -66.0 & -61.3 & -75.6 \\
\hline Non-oil primary fiscal stance & 40.2 & 0.0 & -12.3 & 6.3 & 29.8 & 26.2 & 33.6 & 40.1 & 55.5 \\
\hline Non-oil primary fiscal impulse & 40.9 & -40.2 & -12.3 & 18.6 & 23.4 & -3.6 & 7.4 & 6.5 & 15.4 \\
\hline \multicolumn{10}{|l|}{ Gabon } \\
\hline Non-oil basic fiscal balance & -16.8 & -24.3 & -18.5 & -9.9 & -15.4 & -21.3 & -20.8 & -15.8 & -17.9 \\
\hline Non-oil primary balance & -5.4 & -9.1 & -11.0 & -3.0 & -8.2 & -15.4 & -16.0 & -11.6 & -14.3 \\
\hline Non-oil primary fiscal stance & -4.7 & 0.0 & 1.2 & -7.3 & -2.2 & 5.4 & 6.4 & 2.8 & 5.5 \\
\hline Non-oil primary fiscal impulse & 2.6 & 4.7 & 1.2 & -8.6 & 5.1 & 7.6 & 1.1 & -3.6 & 2.7 \\
\hline \multicolumn{10}{|l|}{ CEMAC } \\
\hline Non-oil basic fiscal balance & -12.3 & -9.0 & -9.8 & -8.6 & -11.5 & -12.1 & -15.8 & -17.1 & -22.4 \\
\hline Non-oil primary balance & -6.1 & -4.3 & -6.7 & -5.1 & -8.1 & -9.1 & -13.3 & -15.4 & -20.7 \\
\hline Non-oil primary fiscal stance & 1.3 & 0.0 & 2.4 & 0.6 & 3.5 & 4.6 & 8.8 & 11.3 & 16.5 \\
\hline Non-oil primary fiscal impulse & 1.7 & -1.3 & 2.4 & -1.8 & 3.0 & 1.1 & 4.1 & 2.5 & 5.3 \\
\hline
\end{tabular}

Source: Country authorities; and IMF staff estimates and projections.

${ }^{1}$ The non-oil basic fiscal balance is defined as the difference between total non-oil revenue (less grants) and total expenditure (less foreign-financed capital outlays); the non-oil primary balance is equal to the sum of non-oil basic fiscal balance and interest payments; The non-oil primary fiscal stance and non-oil primary fiscal impulse are described in details in the text. 
Figure 6. CEMAC Non-oil Real GDP Growth and the Fiscal Impluse, 1995-2008
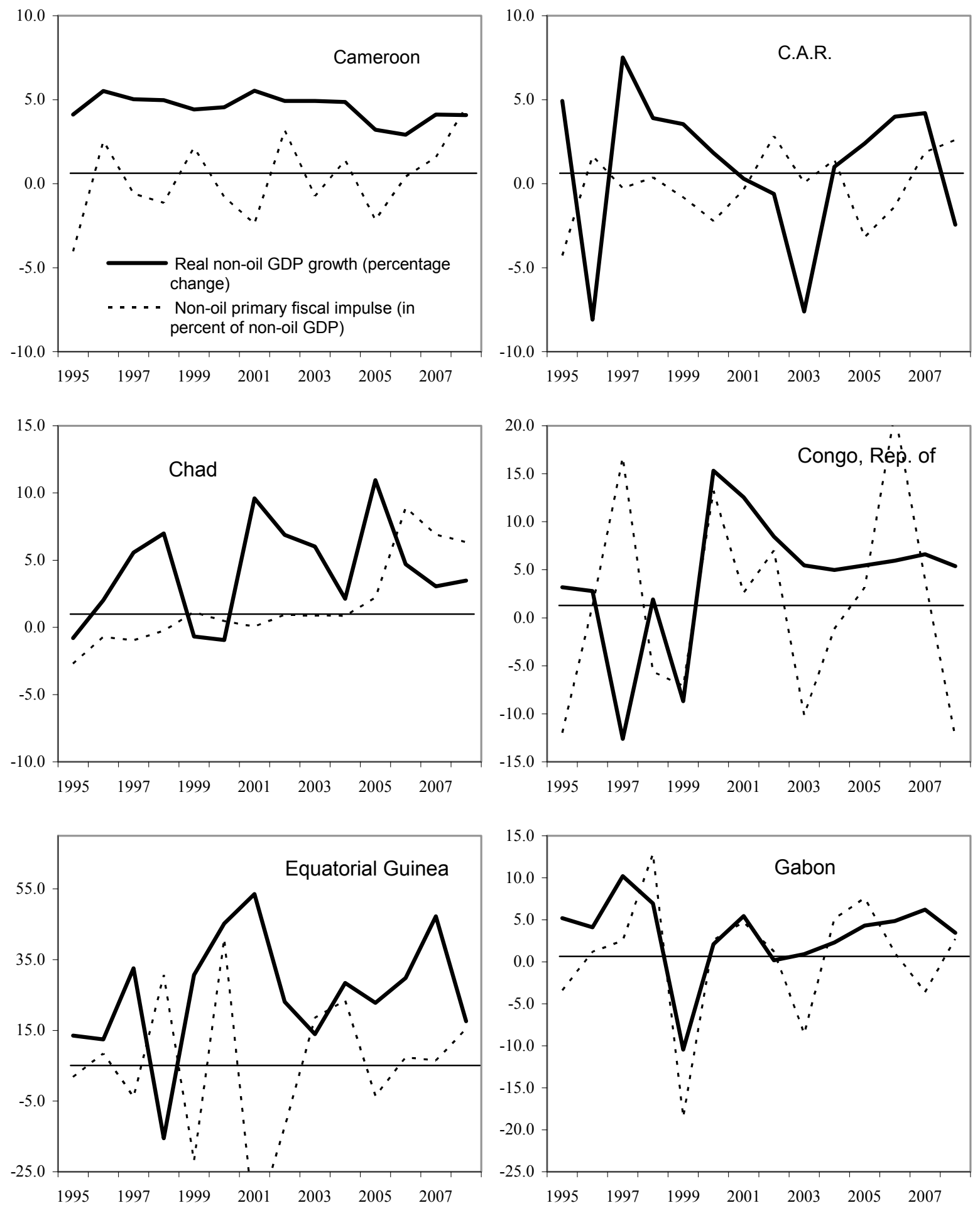

Source: Country authorities; and authors' calculations. 


\section{Indicators of Sustainability}

In the context of bilateral and regional surveillance, we should also be concerned about monitoring a country's fiscal sustainability, and having indicators that could answer questions like the following: Can a country go on with its current fiscal policy, or will it have to increase tax rates, decrease spending, or consider more drastic measures to decrease its debt burden?

\section{Gap-based measures}

Blanchard (1990) suggests a simple indicator of sustainability, the primary gap. It is defined as the change in the primary deficit needed to stabilize the debt ratio at its current level, given the current stance of fiscal policy (Box 7). Whether or not the government has built in future policy tightening (if the tax gap is negative) or loosening (if it is positive), the primary gap measure signals the need for a change in the current policy settings. As Blanchard notes, this indicator is somewhat primitive as it does not take into account predictable changes in economic developments and economic policies. It is a static and backward looking indicator, with the narrow goal of stabilizing the current debt ratio, which itself may not be sustainable or optimal to start with. Applying this indicator in the CEMAC region faces an additional problem that it ignores the exhaustibility of oil reserves. Nonetheless, the primary gap indicator does have the advantage of being easily understood and does not rely on forecasts or other extensive information to produce.

The results of our estimate of the primary gap for the six CEMAC members are reported in Table 4 and plotted against external debt in Figure 7. These estimates are based on external rather than public debt as suggested by equation (3) in Box 7, because we lack comprehensive data on public debt. If domestic debt is significant, our estimate of the primary gap would be biased downward.

- $\quad$ Except for the C.A.R., the estimated primary gaps show that over the last decade fiscal policies have generally moved toward sustainable positions (positive primary gaps) - a view that is at odds with the generally expansionary thrust of policy over most of this decade (see discussion in Section III.B above).

- $\quad$ This result highlights the weakness of the design of the primary gap measure, and the impact of the favorable economic environment over the period. Recall that the primary gap is affected by two elements: actual primary balance and the difference between real growth and the real interest rate. In recent years, the fiscal positions in CEMAC oilproducing countries measured by the primary balance were generally improving because of sharply rising world oil prices; and real GDP growth, boosted by oil production, generally exceeded the real interest rate (the assumed nominal interest rate is 6 percent). These two elements combine to suggest that the primary surpluses being observed were 
more than sufficient to stabilize the external debt-to-GDP ratio. ${ }^{8}$ We would note that this situation is exceptional and it also demonstrates the dangers in relying on a single shortterm static indicator of sustainability. Indeed, the rules-based measures paint a different picture of developments.

\section{Box 7. The Primary Gap Measure}

Consider the dynamic government budget constraint, which is given by

$$
\mathrm{dB} / \mathrm{ds}=\mathrm{G}+\mathrm{H}-\mathrm{T}+\mathrm{rB}=\mathrm{D}+\mathrm{rB}
$$

where $\mathrm{s}$ is time, $\mathrm{B}$ is net public debt, $\mathrm{G}$ is government spending on goods and services, $\mathrm{H}$ is transfers, and $\mathrm{T}$ is taxes, $\mathrm{D}$ is the primary deficit (i.e., $\mathrm{G}+\mathrm{H}-\mathrm{T}$ ), and $\mathrm{r}$ is the real interest rate. The budget constraint shows that the change in the level of public debt is equivalent to the primary surplus or deficit plus the net interest charges on current debt. We could rewrite equation (1) in terms of ratios to GDP (denoted in lower case letters) to yield

$$
\mathrm{db} / \mathrm{ds}=\mathrm{g}+\mathrm{h}-\mathrm{t}+(\mathrm{r}-\theta) \mathrm{b}=\mathrm{d}+(\mathrm{r}-\theta) \mathrm{b}
$$

where $\theta$ is the rate of growth of GDP. From the point of view of sustainability, fiscal policy could be thought of as a sequence of spending and taxing decisions, given the initial value of the debt stock (b). Fiscal policy would be sustainable if real debt does not explode faster than the real interest rate-in other words, if the ratio of real debt to GDP does not explode faster than the excess of the real interest rate over the growth rate. If it is sustainable, then the intertemporal budget constraint holds and the present value of primary surpluses, discounted at the rate $r-\theta$, equals the initial debt-to-GDP ratio; in mathematical terms:

(3) $\int \mathrm{d} \mathrm{e} \mathrm{e}^{-(\mathrm{r}-\theta) \mathrm{s}} \mathrm{ds}=\mathrm{b}_{0}$

where the integral runs from zero to infinity and $b_{0}$ is the initial stock of debt. Fiscal sustainability implies that debt cannot be serviced indefinitely by issuing new debt. If the intertemporal budget constraint does not hold ex ante, then the government must take measures-increase taxes, cut spending, or both — to ensure that debt does not explode.

Table 4. Primary Gap Measure Across the CEMAC, 1998-2008 (in percent of GDP) ${ }^{1}$

\begin{tabular}{lrrrrrrrrrrr}
\hline & 1998 & 1999 & 2000 & 2001 & 2002 & 2003 & 2004 & 2005 & 2006 & 2007 & 2008 \\
\hline Cameroon & 5.0 & 4.6 & 5.0 & 7.2 & 5.6 & 2.8 & 1.1 & 4.4 & 6.4 & 4.3 & 2.0 \\
Central African Republic & -10.6 & -10.4 & -5.6 & -4.5 & -6.5 & -12.3 & -10.7 & -8.0 & 0.4 & -1.9 & -0.7 \\
Chad & 3.3 & -10.5 & -4.3 & 9.9 & 2.4 & 0.7 & 8.7 & 3.0 & 4.8 & 1.4 & 5.7 \\
Congo, Republic of & -6.1 & -7.1 & 11.8 & 4.2 & 4.4 & -0.9 & 12.3 & 25.2 & 25.7 & 7.5 & 33.9 \\
Equatorial Guinea & 9.4 & 13.1 & 3.8 & 30.9 & 21.5 & 13.5 & 14.6 & 21.0 & 23.5 & 18.0 & 15.4 \\
Gabon & -11.0 & 14.5 & 15.6 & 15.4 & 7.2 & 14.0 & 10.2 & 11.9 & 10.4 & 13.2 & 14.2 \\
\hline
\end{tabular}

Source: Author's calculations.

${ }^{1} \mathrm{~A}$ negative sign indicates the need for spending decreases and/or tax increases to prevent a debt explosion.

${ }^{8}$ The declines in the external debt-to-GDP ratio also reflect various debt rescheduling and relief initiatives. 
Figure 7. CEMAC External Debt and the Primary Gap, 1998-2008

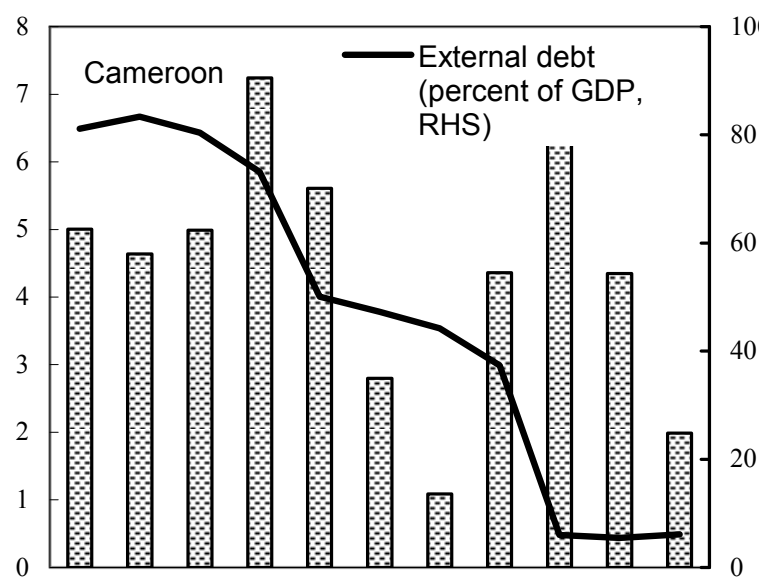

19981999200020012002200320042005200620072008
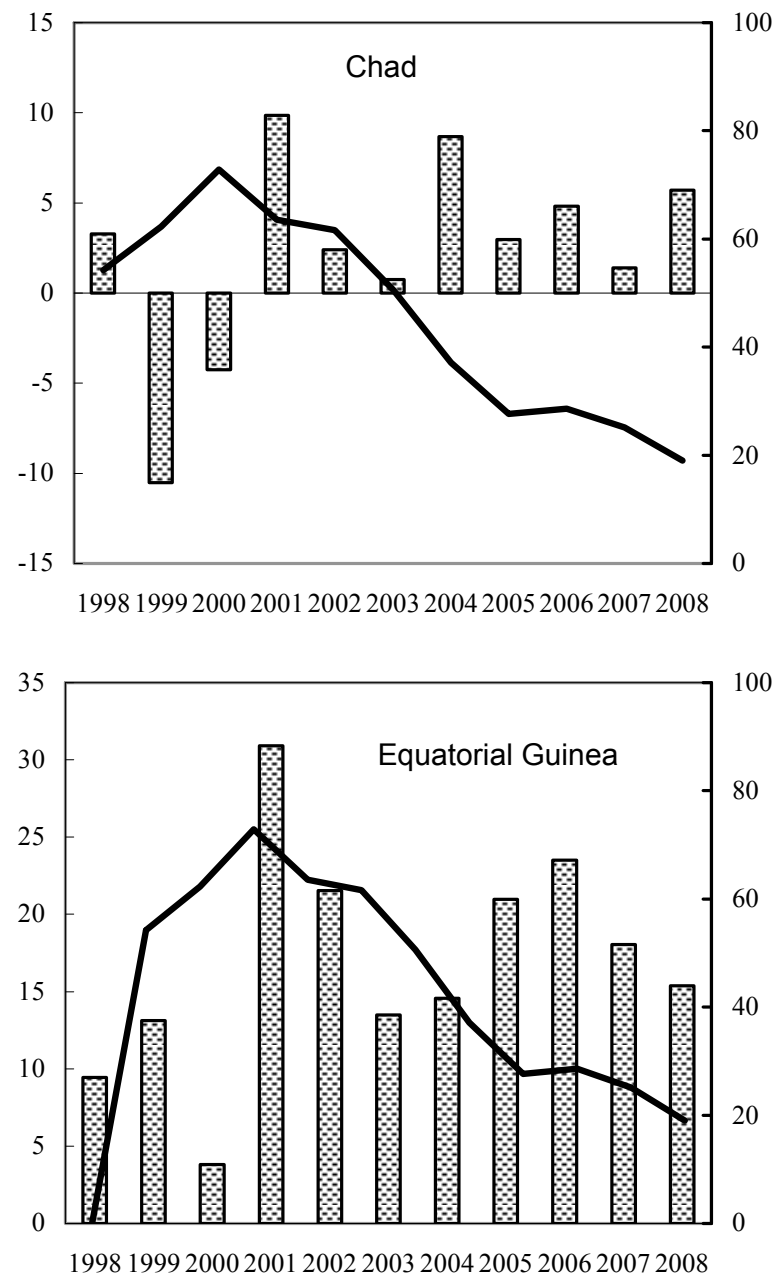

Source: Country authorities; and authors' calculations.

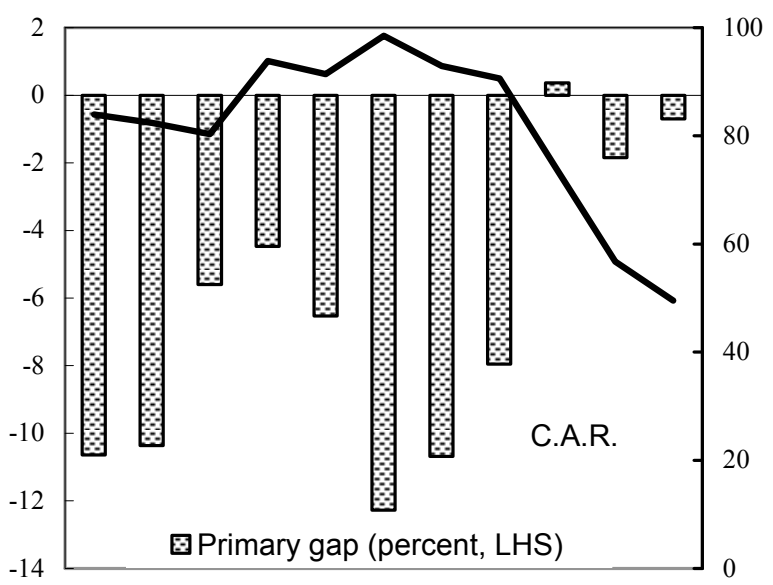

19981999200020012002200320042005200620072008
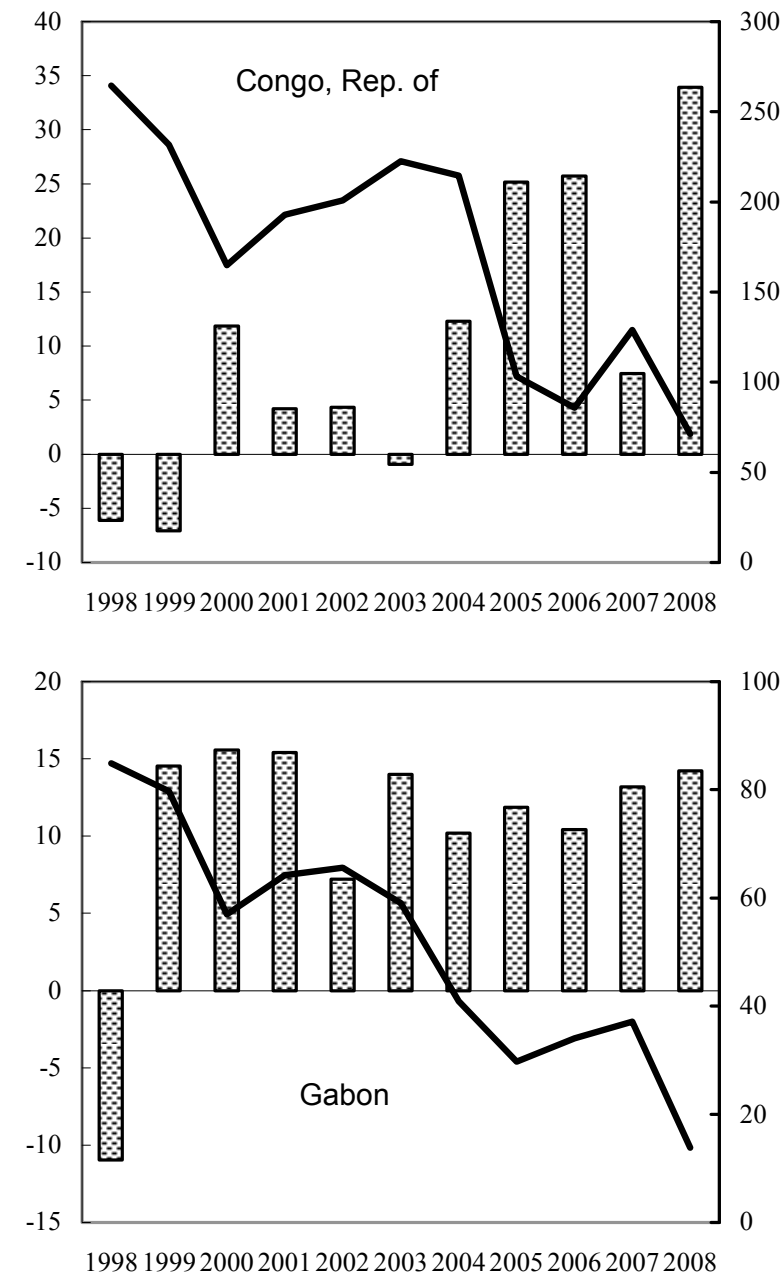


\section{Rule-based measures}

A number of studies focus on the non-oil primary balance as the relevant indicator of how initial conditions and resource endowments in oil-producing countries can influence long-term sustainability in several different models of fiscal rules. Using the approach of York and Zhan (2009), we consider three models for long-term fiscal sustainability: (i) a conservative bird-in hand rule, where government would turn its oil resources into financial assets and commit to spend each year only the projected return on those assets; (ii) a spend-thrift balanced-budget rule, where the government would adopt a balanced budget over the relevant time horizon and use up each year's (projected) oil revenue in the process; and (iii) a constant expenditure rule based on Freidman's (1957) notion of the permanent-income hypothesis, where the government would spend only the permanent (annual) income from its oil-generated wealth, thus ensuring sustainability by maintaining a constant real expenditure path beyond the lifetime of oil reserves (Box 8). ${ }^{9}$ These rules-based models are data-intensive but not difficult to estimate; the key economic data are long-term assumptions and projections for oil (and gas) reserves, world oil prices, real GDP growth and inflation, real interest rates, and population growth.

Table 5. CEMAC Long-Term Macroeconomic Assumptions (In percent unless otherwise noted)

\begin{tabular}{lc}
\hline Non-oil sector real growth rate & 4.0 \\
Real interest rate & 4.0 \\
Population growth & 2.5 \\
Starting balance of oil funds as of end-2008 (\$) & 0.0 \\
World oil prices (US\$ per barrel) & \\
$2009-14^{1}$ & $61.53-84.75$ \\
$2015-48$ & Real prices are constant at \\
& the 2014 level \\
Discount to world oil prices & 10.0 \\
Consumer Price Inflation (CPI) in advanced economies & \\
$2009-14^{1}$ & $0.35-1.64$ \\
$2015-48$ & 1.64 \\
\hline
\end{tabular}

${ }^{1}$ Based on the October 2009 World Economic Outlook assumptions.

Based on a set of homogenous assumptions for all the countries (Table 5) we estimate in the baseline that ${ }^{10}$

- As a group, the fiscal stance of the CEMAC countries in 2008 was far from sustainable, except under the balanced budget rule, which is a comparatively extreme position and

\footnotetext{
${ }^{9}$ Under the constant expenditure rule, we also consider the case of maintaining constant real per capita expenditure to demonstrate the impact of treating current and future generations equally.

${ }^{10}$ We would like to note that our results differ from those of IMF country teams, which rely on country-specific assumptions and policy considerations, and possibly different approaches to long-term sustainability than we employ here.
} 
would imply drastic fiscal adjustments down the road when oil reserves are depleted (Figure 8 and Table 6).

- $\quad$ Achieving a sustainable non-oil primary deficit for most CEMAC countries would require sizable adjustments, even in the short run. Comparing each country's actual nonoil primary deficit for 2008 against estimated sustainable levels for 2009-13, we find that under a relatively conservative fiscal rule of maintaining constant per capita real oil wealth over time, none of the CEMAC oil-producing countries, either individually or collectively, has a sustainable non-oil primary deficit. Under the fiscal rule of maintaining constant real oil wealth over time, only Gabon achieves sustainability, Cameroon and Congo are close, but Chad and Equatorial Guinea continue to be relatively far away. Chad's non-oil primary deficit was $281 / 2$ percent of non-oil GDP for 2008 ; the estimated sustainable deficit would be 10 percent under a constant real wealth rule based on the permanent income hypothesis; and Equatorial Guinea's deficit at over 75 percent of non-oil GDP is very far from even a generous interpretation of fiscal sustainability (i.e., the balanced-budget rule).

- $\quad$ Under the two more conservative fiscal rules, constant real per capita oil wealth where a government would treat the current generation and future generations equally in terms of sharing oil wealth, and the bird-in-hand rule where a government spends as if there were no future oil revenue, all CEMAC oil-producing countries' fiscal positions are not sustainable either individually or as a group.

- $\quad$ The above results are mostly robust with respect to different assumptions about world oil prices (Figure 9), even though higher/lower world oil price assumptions would increase/reduce the sustainable levels of the non-oil primary deficit. Even with very optimistic assumptions on oil prices, say 50 percent higher than the October 2009 World Economic Outlook baseline, the non-oil primary deficit in Cameroon, Chad and Equatorial Guineas as well as the CEMAC region as a whole in 2008 is not sustainable. With higher oil prices, Congo would cross the sustainable threshold under the fiscal rule of constant oil wealth.

York and Zhan (2009) also demonstrate that these results would not change significantly with different assumptions about real interest rates and the introduction of oil price uncertainty. They also show that the results are unlikely to be affected by different definitions of the level of oil reserves, although a significant expansion would increase the long-term sustainable deficit that is consistent with sustainability, other things being equal. Nonetheless, there are some caveats about the results that must be recognized. Allowing for variation, and, presumably positive feedback in the growth of the non-oil sector in response to public investment, could materially affect the estimates. To the extent that higher and front-loaded public investment (in health, education, and economic infrastructure) could increase the rate of non-oil sector growth, running a non-oil primary deficit above the long-term sustainable estimate might be appropriate, at least for a brief period of time. 


\section{Box 8. Constant Fiscal Expenditure Rule for Oil Producing Countries}

Milton Freidman (1957) suggested that consumption behavior is determined by lifetime or long-term income expectations, rather than by current income. Analogous to Freidman's notion of permanent income, Barnett and Ossowski (2003) show that long-term fiscal sustainability requires a government with exhaustible assets, such as oil reserves, to follow a constant real expenditure path that can be financed from the oil wealth indefinitely. In its simplest form, the government chooses a tax and spending policy to maximize a social welfare function, subject to an inter-temporal budget constraint and a transversality condition:

$$
\begin{aligned}
& \underset{\left\{G_{t}\right\}}{\operatorname{Max}} \sum_{s=t}^{\infty} \beta^{s-t} \mathrm{U}\left(\mathrm{G}_{\mathrm{t}}\right), \\
& \text { s.t. } \quad \mathrm{B}_{\mathrm{t}}=\mathrm{RB}_{\mathrm{t}-1}+\mathrm{G}_{\mathrm{t}}-\mathrm{T}-\mathrm{Z}_{\mathrm{t}}, \\
& \text { and } \quad \lim _{s \rightarrow \infty} \mathrm{B}_{t+s}=0
\end{aligned}
$$

where $\beta$ is a discount factor, $G_{t}$ is primary government expenditure, $B_{t}$ is the government debt at the end of the period, $Z_{t}$ is oil revenues that will last for $N$ years from now, $R$ is the interest rate factor $(R=1+r)$, and $\mathrm{T}$ is non-oil revenues. For simplicity, $\mathrm{T}$ and $\mathrm{R}$ are assumed to be constant. The solution to the problem is given by the following Euler equation:

$$
U^{\prime}\left(G_{t}\right)=\beta R U^{\prime}\left(G_{t+1}\right) \text {, }
$$

where $U^{\prime}\left(G_{t}\right)$ is the first derivative. Assuming $\beta R=1$, the result emerges that $G_{t}=G_{t=1} \equiv \bar{G}$; that is, government spending should be constant. More formally, spending is equal to the permanent income or the return on the present discounted value of wealth:

$$
\overline{\mathrm{G}}=\mathrm{T}+\mathrm{r} \sum_{\mathrm{i}=\mathrm{t}+1}^{\mathrm{t}+\mathrm{N}} \mathrm{R}^{\mathrm{t}-\mathrm{i}} \mathrm{Z}_{\mathrm{i}}-\mathrm{rB} \mathrm{B}_{\mathrm{t}-1}
$$

where the middle term on the right side of (5) represents the government expenditure $\left(\mathrm{G}^{*}\right)$ that can be financed infinitely from the oil wealth, without reducing the stock of the oil wealth:

$$
\mathrm{G}^{*}=\mathrm{r} \sum_{\mathrm{i}=\mathrm{t}+1}^{\mathrm{t}+\mathrm{N}} \mathrm{R}^{\mathrm{t}-\mathrm{i}} \mathrm{Z}_{\mathrm{i}}
$$

Expression (6) is flexible enough to accommodate population growth and other variations. For example, if a government would like to treat current and future generations equally and to maintain constant real per capita expenditure, we would have the following:

$$
\mathrm{G}^{*}=(\mathrm{r}-\mathrm{n}) \sum_{\mathrm{i}=\mathrm{t}+1}^{\mathrm{t}+\mathrm{N}} \mathrm{R}^{\mathrm{t}-\mathrm{i}} \mathrm{Z}_{\mathrm{i}}
$$

where $\mathrm{n}$ is the population growth rate $(\mathrm{n}<\mathrm{r})$. 
Figure 8. CEMAC Sustainable Non-Oil Primary Deficit Under Different Fiscal Rules, 2009-13 1/ (In percent of non-oil GDP)

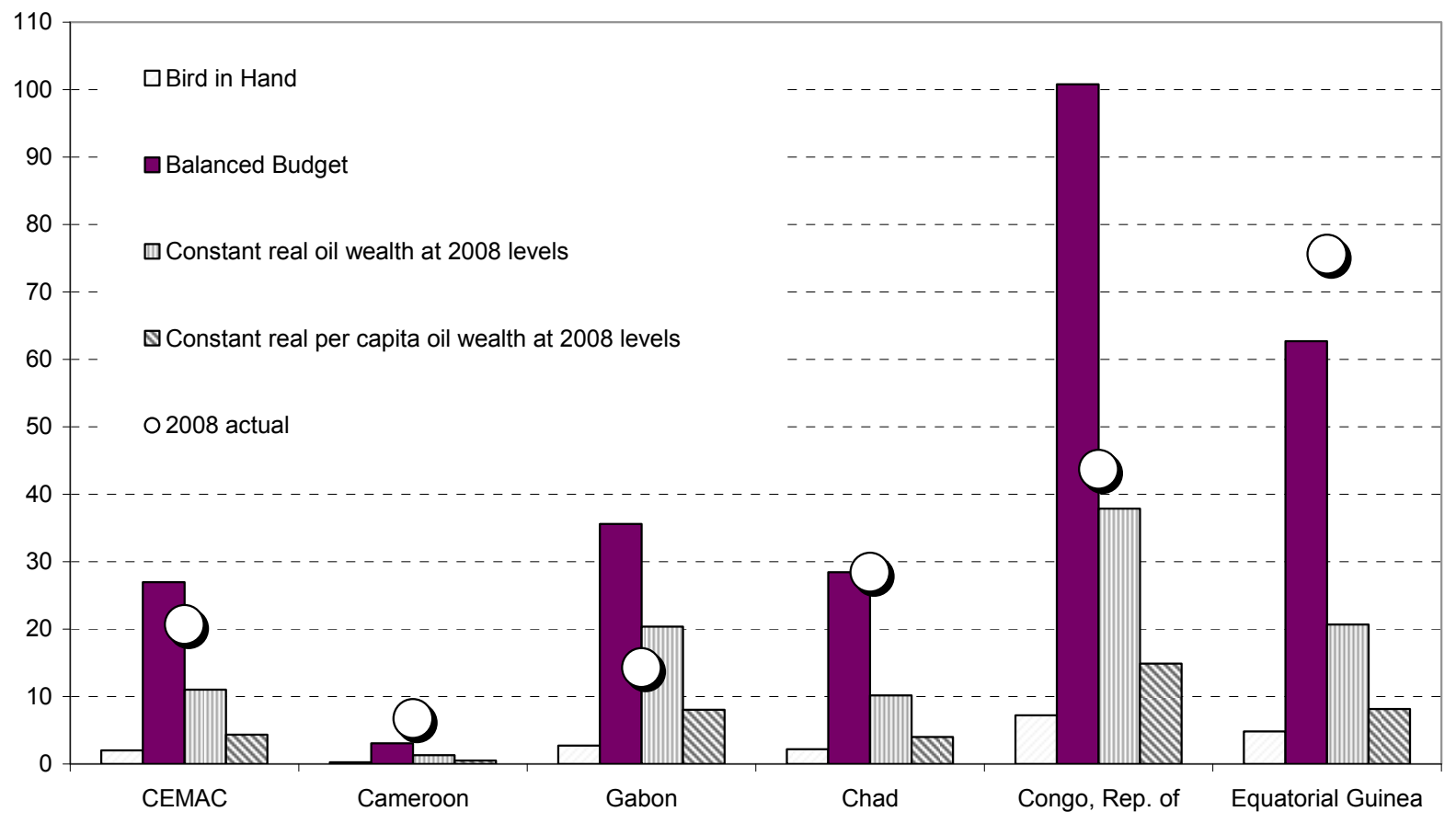

Source: Authors' calculations.

1/ CEMAC includes the C.A.R.

Figure 9. CEMAC Sensitivity of the Sustainable Non-Oil Primary Deficit to Oil Prices Under a Permanent Income Hypothesis, 2009-13 1/

(In percent of non-oil GDP)

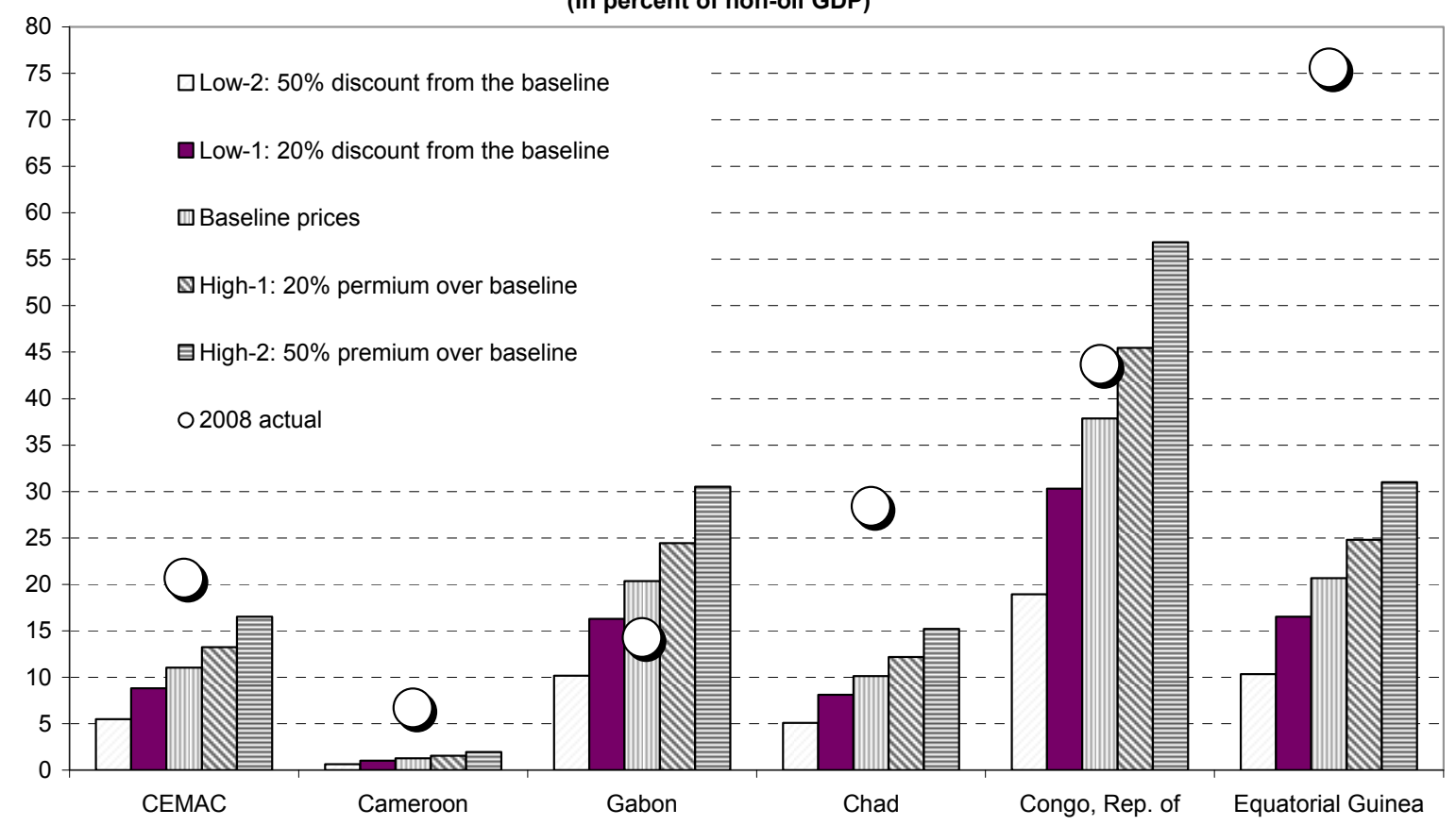

Source: Authors' calculations.

1/ CEMAC includes the C.A.R. 
Table 6. CEMAC Average Sustainable Non-oil Primary Deficit Under Different Fiscal Rules, 2009-48

(In percent of Non-oil GDP)

\begin{tabular}{|c|c|c|c|c|}
\hline & $2009-13$ & $2014-18$ & $2024-28$ & $2029-48$ \\
\hline \multicolumn{5}{|l|}{ Cameroon } \\
\hline Constant real oil wealth at 2008 levels & 1.3 & 1.1 & 0.7 & 0.5 \\
\hline Constant real per capita oil wealth at 2008 levels & 0.5 & 0.5 & 0.4 & 0.3 \\
\hline Bird in Hand & 0.2 & 0.7 & 0.9 & 0.6 \\
\hline Balanced Budget & 3.1 & 2.1 & 0.8 & 0.0 \\
\hline \multicolumn{5}{|l|}{ Gabon } \\
\hline Constant real oil wealth at 2008 levels & 20.4 & 16.7 & 11.3 & 7.1 \\
\hline Constant real per capita oil wealth at 2008 levels & 8.0 & 7.4 & 6.4 & 5.4 \\
\hline Bird in Hand & 2.7 & 7.9 & 11.7 & 10.5 \\
\hline Balanced Budget & 35.6 & 26.1 & 13.8 & 4.9 \\
\hline \multicolumn{5}{|l|}{ Chad } \\
\hline Constant real oil wealth at 2008 levels & 10.1 & 8.3 & 5.6 & 3.5 \\
\hline Constant real per capita oil wealth at 2008 levels & 4.0 & 3.7 & 3.2 & 2.7 \\
\hline Bird in Hand & 2.2 & 6.0 & 6.7 & 4.8 \\
\hline Balanced Budget & 28.4 & 15.2 & 4.3 & 0.5 \\
\hline \multicolumn{5}{|l|}{ Congo, Rep. of } \\
\hline Constant real oil wealth at 2008 levels & 37.9 & 31.1 & 21.0 & 13.2 \\
\hline Constant real per capita oil wealth at 2008 levels & 14.9 & 13.9 & 12.0 & 10.0 \\
\hline Bird in Hand & 7.2 & 22.0 & 26.1 & 17.8 \\
\hline Balanced Budget & 100.8 & 63.0 & 15.6 & 0.5 \\
\hline \multicolumn{5}{|l|}{ Equatorial Guinea } \\
\hline Constant real oil wealth at 2008 levels & 20.7 & 17.0 & 11.5 & 7.2 \\
\hline Constant real per capita oil wealth at 2008 levels & 8.1 & 7.6 & 6.5 & 5.5 \\
\hline Bird in Hand & 4.8 & 13.0 & 14.1 & 9.4 \\
\hline Balanced Budget & 62.7 & 32.3 & 4.3 & 0.4 \\
\hline \multicolumn{5}{|l|}{ CEMAC } \\
\hline Constant real oil wealth at 2008 levels & 11.0 & 9.1 & 7.4 & 6.1 \\
\hline Constant real per capita oil wealth at 2008 levels & 4.3 & 4.0 & 3.7 & 3.5 \\
\hline Bird in Hand & 2.0 & 5.8 & 7.1 & 7.1 \\
\hline Balanced Budget & 26.9 & 16.5 & 9.2 & 5.2 \\
\hline
\end{tabular}

Source: Authors' calculations.

\section{Implications for Fiscal Surveillance}

The CEMAC convergence criterion in the fiscal area - non-negative basic balance-does not provide an appropriate benchmark against which to assess fiscal policy in each member country and in the region as a whole. It suffers from at least two shortcomings. First, it fails to take into account the cyclical nature of each economy and would make the implementation of countercyclical fiscal policies difficult. Second, it fails to recognize that five of the six CEMAC countries are oil producers, and oil revenue should be treated as financing instead of income, and should therefore be isolated from the fiscal balance for the current period. To improve the fiscal surveillance in the CEMAC region, we propose that the member countries focus more on the fiscal stance and fiscal impulse, excluding oil revenue, for judging the short-term direction of fiscal policy, and rely on the non-oil primary balance for assessing the medium-to long-term fiscal sustainability. The recent adoption of the adjustment criterion on the non-oil basic fiscal balance is a step forward but does not go far enough. 


\section{EXTERNAL SHOCKS AND THE CONVERGENCE CRITERIA}

As well as better fiscal indicators, we argue that the CEMAC Commission should extend its monitoring to cover recent economic developments, including the cyclical position of member countries and external shocks they may have faced. We do not have a set of convergence criteria to propose that could cover such developments, but we highlight the importance of such developments in providing the context in which to assess performance, relative to the current convergence criteria. In other words, the business cycle matters, as does the nature of external shocks when judging whether or not the indicators point to member countries' progress toward convergence or deviation because of factors beyond their control.

The data show that CEMAC countries have experienced volatile economic cycles over the past several decades and this has complicated surveillance and the achievement of the convergence criteria. Real non-oil GDP growth has moved by two digits or more in both directions (Table 7), with a standard deviation ranging from 4.8 percent in Cameroon to 17 percent in Equatorial Guinea. Also, the data indicate - somewhat surprisingly, given their similar economic structures and reliance on oil resources - that their economic cycles in terms of non-oil GDP are not synchronized. Five of the six members (except Gabon) have negative cross-country output correlations across the region (Table 8). Members' reactions to this volatility and idiosyncratic shocks are restricted to fiscal policies, given the monetary union and fixed exchange rate.

In this section we closely examine the scope and nature of external shocks and their impact on growth, and assess the effectiveness of fiscal policy in mitigating them. This will help shed light on how member countries might react to shocks, and how these reactions could be considered in the context of surveillance.

Table 7. Real Non-oil GDP Growth in CEMAC Countries, 1980-2008

\begin{tabular}{|c|c|c|c|c|c|c|}
\hline & Observations & Mean & Median & Std. Dev. & Min & Max \\
\hline Cameroon & 28 & 3.0 & 4.3 & 4.8 & -7.9 & 15.0 \\
\hline CAR & 28 & 1.3 & 1.8 & 5.0 & -8.1 & 13.0 \\
\hline Chad & 28 & 4.3 & 5.0 & 4.9 & -10.8 & 15.7 \\
\hline Congo & 28 & 3.4 & 2.4 & 8.9 & -12.6 & 28.8 \\
\hline Equatorial Guinea & 28 & 14.3 & 12.7 & 17.0 & -15.5 & 53.6 \\
\hline Gabon & 28 & 2.2 & 3.6 & 6.9 & -21.1 & 17.2 \\
\hline
\end{tabular}

Source: IMF staff estimates.

Table 8. Correlation of Real Non-oil GDP Growth Among CEMAC Countries, 1980-2008

\begin{tabular}{lrrrrrr}
\hline & Cameroon & CAR & Chad & Congo & $\begin{array}{c}\text { Equatorial } \\
\text { Guinea }\end{array}$ & Gabon \\
\hline Cameroon & $\ldots$ & 0.43 & -0.23 & -0.29 & 0.23 & 0.21 \\
CAR & 0.43 & $\ldots$ & -0.35 & -0.12 & 0.13 & 0.27 \\
Chad & -0.23 & -0.35 & $\ldots$ & 0.09 & -0.02 & 0.22 \\
Congo & -0.29 & -0.12 & 0.09 & $\ldots$ & 0.09 & 0.17 \\
Equatorial Guiea & 0.23 & 0.13 & -0.02 & 0.09 & $\ldots$ & 0.06 \\
Gabon & 0.21 & 0.27 & 0.22 & 0.17 & 0.06 & $\ldots$ \\
\hline
\end{tabular}

Source: IMF staff estimates. 


\section{A. External Shocks and Growth}

The volatile economic cycles in CEMAC member countries described above were caused by various domestic and external shocks (Table 9). Among domestic shocks, conflict and political instability appear to be the main factors driving output volatility within the region. At the same time, movements in the terms of trade and the real effective exchange rate appear to be the main factors on the external side.

Over the period 1980-2008, the terms of trade and the real effective exchange rate fluctuated widely as shown in Figure 10. In all countries except the C.A.R., the standard deviation of annual changes in the terms of trade exceeded 15 percent, while movements in the real effective exchange rate were less dramatic, the standard deviation still stood at about 10 percent for all countries. The contemporaneous correlation of non-oil economic growth with these external factors is relatively modest across the six countries (Table 10).

Table 9. Triggers of Recessions in CEMAC Countries, selected periods ${ }^{1}$

\begin{tabular}{|c|c|c|c|}
\hline Country & Year & External factors & Domestic factors \\
\hline Cameroon & late-1980s & REER and TOT shock & \\
\hline$\overline{C A R}$ & $\begin{array}{c}\text { late-1980s } \\
\text { early-1980s } \\
\text { mid-1990s } \\
\text { early-2000s }\end{array}$ & $\begin{array}{c}\text { TOT shock } \\
\text { Drought } \\
\text { TOT shock } \\
\ldots\end{array}$ & $\begin{array}{c}\ldots \\
\ldots \\
\ldots \\
\text { Military conflict }\end{array}$ \\
\hline Chad & $\begin{array}{l}\text { mid-1990s } \\
\text { early-2000s }\end{array}$ & $\begin{array}{c}\text {... } \\
\text { TOT shock }\end{array}$ & $\begin{array}{c}\text { Political turmoil } \\
\ldots\end{array}$ \\
\hline Congo & $\begin{array}{l}\text { mid-1990s } \\
\text { late-1990s }\end{array}$ & $\begin{array}{l}\ldots \\
\ldots\end{array}$ & $\begin{array}{c}\text { Political conflict } \\
\text { Civil war }\end{array}$ \\
\hline $\begin{array}{l}\text { Equatorial } \\
\text { Guinea }\end{array}$ & late-1990s & REER and TOT shock & $\ldots$ \\
\hline Gabon & $\begin{array}{l}\text { late-1980s } \\
\text { early-1990s } \\
\text { late-1990s }\end{array}$ & $\begin{array}{l}\cdots \\
\cdots \\
\cdots\end{array}$ & $\begin{array}{l}\text { Sharp retrenchment of public investment } \\
\text { Political turmoil } \\
\text { Sharp retrenchment of public investment }\end{array}$ \\
\hline
\end{tabular}


Figure 10. Terms of Trade and Real Effective Exchange Rates, 1980-2008
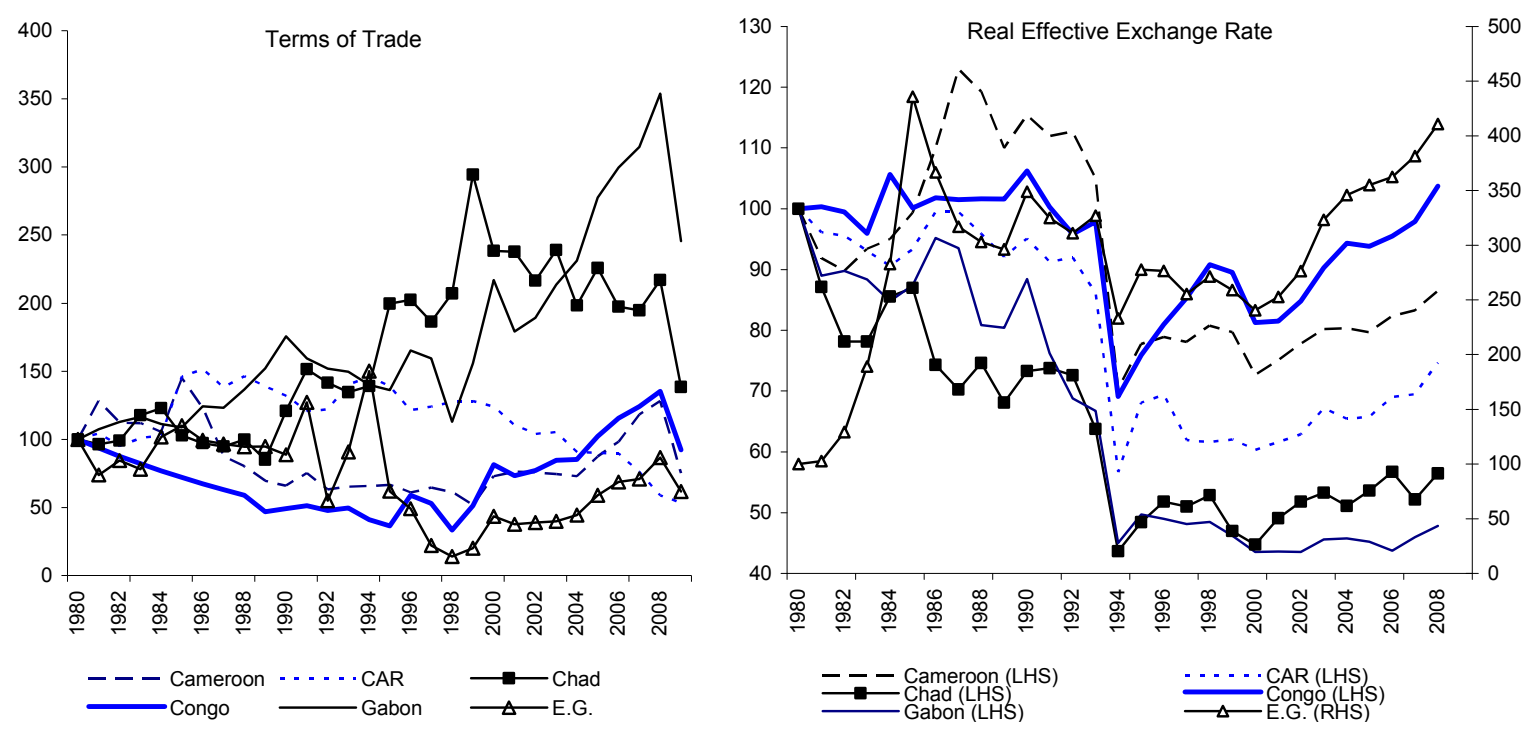

Source: National authorities; and IMF staff estimates.

Table 10. Correlation Between Real GDP and External Factors, 1980-2008

\begin{tabular}{|c|c|c|c|c|c|c|}
\hline & Cameroon & CAR & Chad & Congo & $\begin{array}{c}\text { Equatorial } \\
\text { Guinea }\end{array}$ & Gabon \\
\hline Change in terms of trade & 0.35 & 0.21 & 0.12 & 0.00 & 0.19 & -0.29 \\
\hline Change in real effective exchange rate & 0.19 & -0.13 & 0.29 & 0.13 & -0.15 & -0.03 \\
\hline Change in world oil price & -0.08 & -0.23 & -0.25 & 0.13 & 0.47 & -0.29 \\
\hline Change in global economic growth & -0.34 & 0.17 & -0.02 & 0.10 & 0.06 & -0.40 \\
\hline
\end{tabular}

Source: IMF staff estimates.

The dynamic impact of these two external shocks can be assessed using the vector autoregressive approach (VAR) put forth by Broda (2003) (see Box 9 for details). The analysis suggests that across the CEMAC region the dynamic impact of terms of trade and real effective exchange rate shocks on growth are significant. Figure 11 shows the impulse response functions of real GDP growth $\left(\Delta \ln y_{i t}\right)$ to a positive standard deviation change in the terms of trade $\left(\Delta \operatorname{lnt}_{\mathrm{it}}\right)$ and the real effective exchange rate $\left(\Delta \operatorname{lnn}_{\mathrm{it}}\right)$. The response of real GDP growth to positive terms-of-trade shocks are mainly positive as expected. The cumulative positive impact varies from 0.3 percentage points in Chad to 3.1 percentage points in Equatorial Guinea over ten quarters. In all countries except for Chad, the positive response continues for almost ten quarters with the peak at around the fourth quarter. In Chad, the positive responses rapidly disappear only in three quarters.

The response of real GDP to the appreciation of the real effective exchange rate (i.e. positive change in the real effective exchange rate) are mostly negative as expected, except for Chad. The cumulative impact ranges between 0.3 percentage points in Cameroon to 1.1 percentage points in Equatorial Guinea over ten quarters. With regard to the variance decomposition, the contributions of terms-of-trade shocks to real GDP growth are about 3 percent in Congo and 
Chad, but relatively high at about 10 percent for the other four countries. There appears to be a marginal contribution from real effective exchange rate change for all of them.

\section{Box 9. Measuring the Impact of Exogenous Shocks on the Non-oil Economy}

Following the methodology of Broda (2003), we run the following VAR to assess the importance of shocks in the terms of trade $\left(t_{i t}\right)$ and the real effective exchange rate $\left(r_{i t}\right)$ in driving non-oil business cycles (non-oil real GDP $\left(\mathrm{y}_{\mathrm{it}}\right)$ ), in country $\mathrm{i}$ at time t. The VAR (equation (1)) is based on annual data over the period 1981-2008, which has been interpolated to generate quarterly series for the terms of trade, the real effective exchange rate, output, and fiscal variables.

(1) $\quad Y_{i t}=A(L, q) Y_{i t}+U_{i t}$

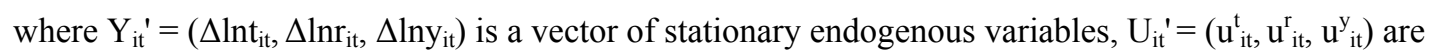
structural errors, $A(L, q)$ is a matrix of polynominals in the lag operator of order $q=2$. The VAR included a trend and dummy variables for the years of political turmoil as exogenous variables. The recursive structure of the VAR was imposed by the ordering of the three variables. Intuitively, it is assumed that the terms-of-trade is the most exogenous relative to other variables given that CEMAC countries are price takers in world markets. The real effective exchange rate is assumed to be less exogenous than the terms-of-trade because domestic inflation is determined by endogenous factors.

Terms of trade and real effective exchange rate shocks could be further exaggerated by fiscal policies, since these policies are highly pro-cyclical as suggested earlier. The correlations between GDP, revenue, and expenditure range between 30 to 70 percent in Cameroon, the C.A.R., Chad, and Gabon, while hovering around 30 percent in Congo and Equatorial Guinea (Table 11). Consequently, the ripple effects of shocks could be magnified through fiscal policies. However, these shocks could be mitigated by counter-cyclical fiscal policies rather than exaggerated by pro-cyclical fiscal policies; a possibility we investigate in the next section.

\section{B. The Efficacy of Fiscal Policies in Mitigating Shocks}

In advanced countries, it has been shown that counter-cyclical fiscal policies (discretionary public spending increases and tax cuts) are effective tools to mitigate the impact of shocks on the business cycle. Because of the large share of the public sector relative to the non-oil economy (Table 12), counter-cyclical fiscal polices could have a mitigating impact on CEMAC countries as well. Using the methodology of Blanchard and Peroti (2002), which is detailed in Box 10, we attempt to quantify the effectiveness of counter-cyclical fiscal policies across CEMAC countries. 
Figure 11. Impulse Response of Output to a One Standard Deviation Change in Terms of Trade and Real Effective Exchange Rate Shocks
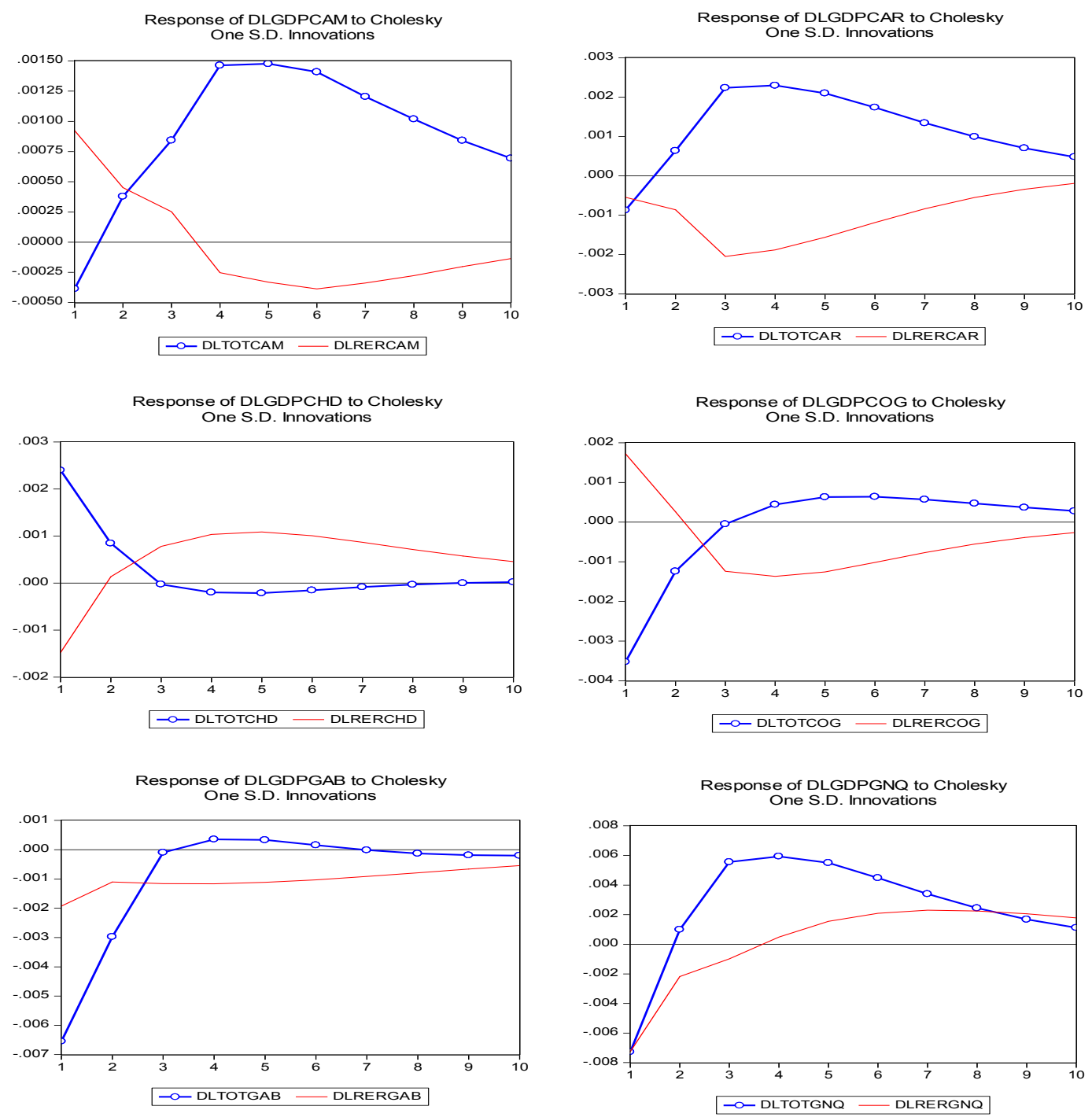

Source: Author's calculations.

Note: $\mathrm{CAM}=$ Cameroon, $\mathrm{CAR}=$ Central African Republic, $\mathrm{CHD}=\mathrm{Chad}, \mathrm{COG}=$ the Republic of Cong, $\mathrm{GAB}=\mathrm{Gabon}$, and GNQ=Equatorial Guinea. DLTOT, DLGDP, and DLRER stand for $\Delta \log$ of terms of trade, $\Delta \log$ of nonoil real $\mathrm{GDP}$, and $\Delta \log$ of real effective exchange rate.

Table 11. Correlation Between Non-oil GDP, Public Expenditure, and Non-oil Revenue

\begin{tabular}{lrrrrrr}
\hline & Cameroon & C.A.R. & Chad & Congo & $\begin{array}{c}\text { Equatorial } \\
\text { Guinea }\end{array}$ & Gabon \\
\hline Correlation $(\Delta \ln$ GDP, $\Delta \ln$ Revenue $)$ & 0.48 & 0.43 & 0.37 & 0.33 & 0.37 & 0.60 \\
Correlation $(\Delta \ln$ Revenue, $\Delta$ ln Expenditure $)$ & 0.31 & 0.46 & 0.52 & 0.28 & 0.05 & 0.67 \\
\hline
\end{tabular}

Source: IMF staff estimates. 
Table 12. Average Share of Non-oil Revenue and Expenditure in Non-Oil GDP, 1980-2008

\begin{tabular}{|c|c|c|c|c|c|c|}
\hline & Cameroon & CAR & Chad & Congo & $\begin{array}{c}\text { Equatorial } \\
\text { Guinea }\end{array}$ & Gabon \\
\hline Nonoil revenue/non-oil GDP & 13.3 & 15.4 & 13.9 & 16.5 & 26.5 & 28.2 \\
\hline Expenditure/non-oil GDP & 18.5 & 18.0 & 19.3 & 50.7 & 56.6 & 51.6 \\
\hline
\end{tabular}

Source: IMF staff estimates.

\section{Box 10. Measuring the Impact of Counter-Cyclical Fiscal Policies on the Non-oil Economy}

We use a VAR representation similar to equation (1) in Box 9 and the methodology of Blanchard and Perotti (2002), where $\mathrm{Y}_{\mathrm{it}}{ }^{\prime}=\left(\mathrm{T}_{\mathrm{it}}, \mathrm{G}_{\mathrm{it}}, \mathrm{X}_{\mathrm{it}}\right)$ is a three-dimensional vector in the logarithms of quarterly real non-oil revenue $\left(\mathrm{t}_{\mathrm{it}}\right)$, spending $\left(\mathrm{g}_{\mathrm{it}}\right)$, and GDP $\left(\mathrm{x}_{\mathrm{it}}\right)$ (all deflated by the GDP deflator). $\mathrm{U}_{\mathrm{it}}{ }^{\prime}=\left(\mathrm{t}_{\mathrm{it}}, \mathrm{g}_{\mathrm{it}}, \mathrm{x}_{\mathrm{it}}\right)$ are structural errors, $A(L, q)$ is a matrix of polynominals in the lag operator of order $q=2$.

The methodology of Blanchard and Perotti allow us to examine the impact of fiscal shocks such as unexpected (or discretionary) spending increases and tax cuts, distinct from the general fiscal stance on growth. Without loss of generality, the structure of equation (1) in Box 9 can be expressed as

$$
\begin{aligned}
& \mathrm{t}_{\mathrm{t}}=\mathrm{a}_{1} \mathrm{x}_{\mathrm{t}}+\mathrm{a}_{2} \mathrm{e}_{{ }_{\mathrm{t}}}^{\mathrm{g}}+\mathrm{e}_{\mathrm{t}}^{\mathrm{t}} \\
& \mathrm{g}_{\mathrm{t}}=\mathrm{b}_{1} \mathrm{x}_{\mathrm{t}}+\mathrm{b}_{2} \mathrm{e}_{\mathrm{t}}^{\mathrm{t}}+\mathrm{e}^{\mathrm{g}}{ }_{\mathrm{t}} \\
& \mathrm{x}_{\mathrm{t}}=\mathrm{c}_{1} \mathrm{t}_{\mathrm{t}}+\mathrm{c}_{2} \mathrm{~g}_{\mathrm{t}}+\mathrm{e}_{\mathrm{t}}^{\mathrm{x}}
\end{aligned}
$$

where $\mathrm{e}_{\mathrm{t}}^{\mathrm{t}}, \mathrm{e}_{\mathrm{t}}^{\mathrm{g}}$, and $\mathrm{e}_{\mathrm{t}}^{\mathrm{x}}$ are the mutually uncorrelated structural shocks. Equation (2) represents the unexpected movements in revenue within a quarter in response to unexpected movement in GDP, structural spending, and structural revenue shocks. Equation (3) is the similar representation for unexpected spending, with equation (4) as the unexpected movements in GDP in response to unexpected movements in revenue, spending, and other unanticipated shocks. These three equations embody the notion that fiscal shocks (coming, for example, from an unanticipated revenue decline from tax cuts, or an unanticipated spending increase from a stimulus package) could contribute to output variations, under a given fiscal stance. In this way, we hope to also identify the effectiveness of counter-cyclical fiscal policies.

The VAR analysis suggests that fiscal policy could be an effective counter-cyclical tool in the CEMAC region; in other words, increasing government spending could help mitigate the adverse impact of a negative external shock on output. Figure 12 shows the impulse response function of one positive standard deviation change in revenue and spending shock variables on the point estimates. The effect of a positive spending shock (unexpected or discretionary government spending increase) on growth is mostly positive as expected, except for Chad and Equatorial Guinea. In Cameroon, the C.A.R., Congo, and Gabon the positive responses continue for more than a year. The cumulative positive impact is about 1 percentage points over ten quarters in Cameroon, the C.A.R., Congo, and 9 percentage points in Gabon. In comparison, the effect of a positive revenue shock (unexpected or discretionary tax increase) on growth is mainly positive, 
which is counter-intuitive and contrasts with the cases in advanced economies. This is puzzling and deserves further investigation. ${ }^{11}$

With regard to the variance decomposition, the contribution of spending shocks to real GDP growth are relatively high at over 40 percent at the peak in Chad and Gabon, about 10 percent at the peak in Cameroon and Equatorial Guinea, and marginal in the C.A.R. and Congo (Table 13). These results suggest that an unexpected spending increase could be helpful in mitigating against an output decline caused by external factors. For national governments with limited macroeconomic policy tools at their disposal, this is an important finding.

\section{Implications for Regional Surveillance}

The long experience across the CEMAC region and the empirical analysis in this section suggests that the terms of trade and real effective exchange rate shocks have had significant impact on output variability, but the magnitude surprisingly varies across countries. Also, an unexpected (or discretionary) government spending increase appears to have a positive impact on growth, indicating that counter-cyclical fiscal policies could be effective in mitigating a decline in output caused by external shocks. In our view, this points to a clear need - in the context of surveillance - to consider the impact of external shocks and cyclical factors on fiscal performance.

Regrettably, external shocks are not considered and play no role in the region's surveillance agenda, or convergence criteria. This is an unfortunate oversight since external shocks are an inherent feature of a region heavily dependent on commodities (oil and minerals), which are themselves subject to a high degree of volatility.

To be more effective, the regional surveillance agenda could, therefore, take into account the cyclical position of member countries and the nature of shocks affecting them, when interpreting macroeconomic performance relative to the convergence criteria. In particular, it could also take account of counter-cyclical fiscal measures when judging observance; this is a point stressed in Section III above, as the current convergence criteria does not allow for such a possibility.

\footnotetext{
${ }^{11}$ One possible explanation of this counter-intuitive result is that we used total non-oil revenue instead of tax revenue due to data availability. In this case, a positive revenue shock does not necessarily indicate discretionary tax increases because the positive shock could come from increased non-tax revenue.
} 
Figure 12. Impulse Response of Output to a One Standard Deviation Change in Revenue and Spending Shocks
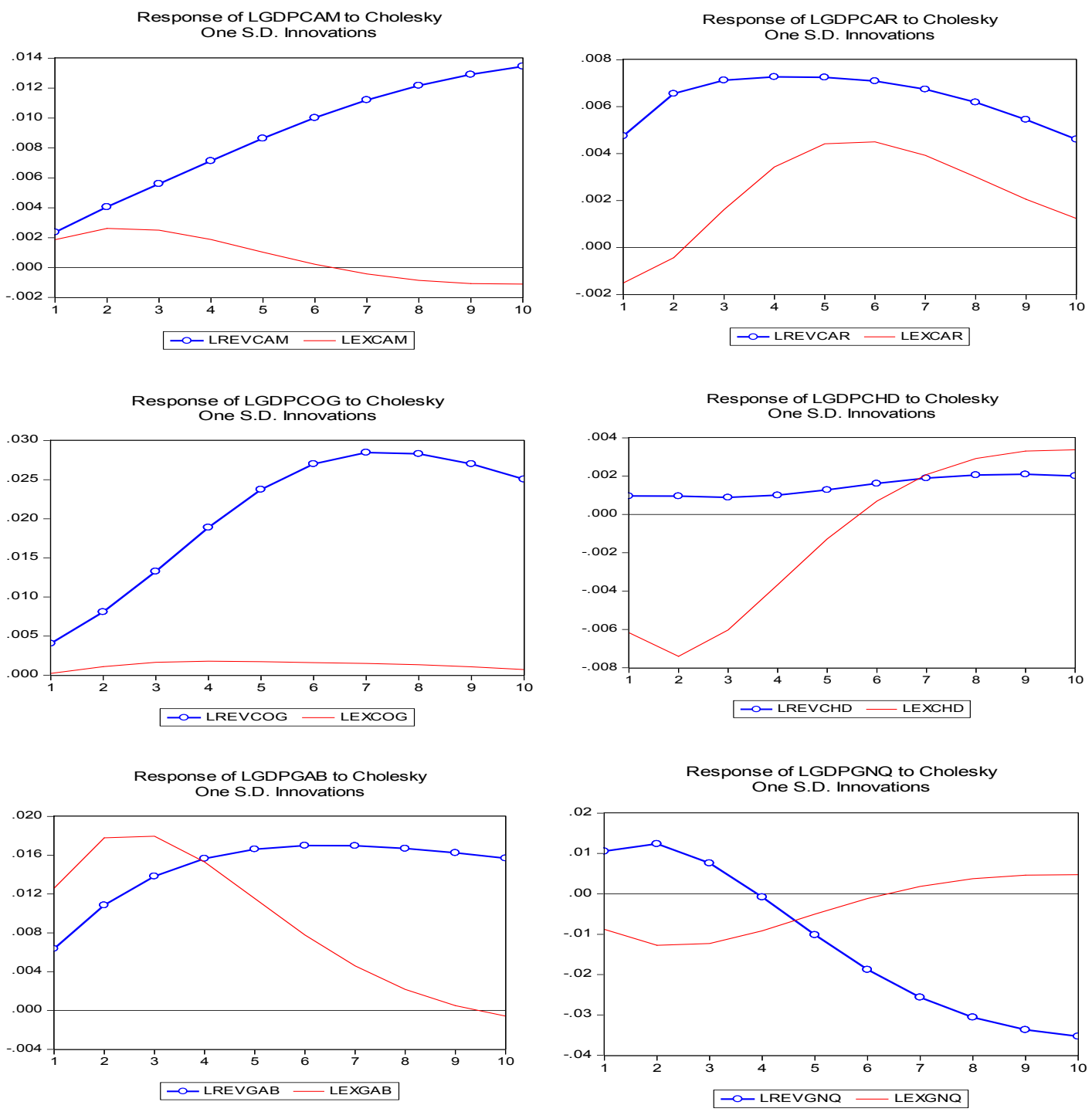

Source: Author's calculations.

Note: $\mathrm{CAM}=$ Cameroon, $\mathrm{CAR}=$ Central African Republic, $\mathrm{CHD}=\mathrm{Chad}, \mathrm{COG}=$ the Republic of $\mathrm{Cong}, \mathrm{GAB}=\mathrm{Gabon}$, and GNQ=Equatorial Guinea. LGDP, LREV, and LEX stand for log of nonoil real GDP, log of nonoil fiscal revenues, and log of fiscal spending. 
Table 13. Variance Decomposition of Real GDP by Types of Shocks (share of total volatility, in percent)

\begin{tabular}{|c|c|c|c|c|c|c|}
\hline \multirow[b]{2}{*}{ Period } & \multicolumn{3}{|c|}{ Cameroon } & \multicolumn{3}{|c|}{ C.A.R. } \\
\hline & Rev. & Exp. & GDP & Rev. & Exp. & GDP \\
\hline 1 & 15.8 & 9.9 & 74.3 & 12.9 & 1.6 & 85.5 \\
\hline 2 & 14.9 & 7.0 & 78.1 & 10.7 & 0.6 & 88.6 \\
\hline 3 & 14.9 & 4.6 & 80.5 & 9.6 & 0.4 & 90.0 \\
\hline 4 & 15.5 & 3.0 & 81.6 & 9.1 & 0.7 & 90.2 \\
\hline 5 & 16.3 & 1.9 & 81.8 & 9.1 & 1.1 & 89.9 \\
\hline 6 & 17.1 & 1.3 & 81.6 & 9.4 & 1.4 & 89.2 \\
\hline 7 & 18.0 & 0.9 & 81.1 & 9.9 & 1.5 & 88.6 \\
\hline 8 & 18.7 & 0.7 & 80.5 & 10.4 & 1.6 & 88.0 \\
\hline 9 & 19.4 & 0.6 & 80.0 & 10.9 & 1.6 & 87.5 \\
\hline \multirow{2}{*}{10} & 20.0 & 0.5 & 79.4 & 11.4 & 1.6 & 87.0 \\
\hline & \multicolumn{3}{|c|}{ Chad } & \multicolumn{3}{|c|}{ Congo } \\
\hline Period & Rev. & Exp. & GDP & Rev. & Exp. & GDP \\
\hline 1 & 1.0 & 41.3 & 57.7 & 4.6 & 0.0 & 95.4 \\
\hline 2 & 0.6 & 32.2 & 67.2 & 6.7 & 0.1 & 93.2 \\
\hline 3 & 0.5 & 24.6 & 74.9 & 10.4 & 0.2 & 89.5 \\
\hline 4 & 0.5 & 18.8 & 80.7 & 15.2 & 0.2 & 84.6 \\
\hline 5 & 0.5 & 15.0 & 84.5 & 20.4 & 0.2 & 79.5 \\
\hline 6 & 0.7 & 12.7 & 86.6 & 24.9 & 0.2 & 75.0 \\
\hline 7 & 0.9 & 11.6 & 87.5 & 28.4 & 0.2 & 71.4 \\
\hline 8 & 1.1 & 11.2 & 87.7 & 31.0 & 0.1 & 68.9 \\
\hline 9 & 1.3 & 11.2 & 87.4 & 32.7 & 0.1 & 67.2 \\
\hline \multirow[t]{2}{*}{10} & 1.5 & 11.4 & 87.1 & 33.9 & 0.1 & 66.0 \\
\hline & \multicolumn{3}{|c|}{ Gabon } & \multicolumn{3}{|c|}{ Equatorial Guinea } \\
\hline Period & Rev. & Exp. & GDP & Rev. & Exp. & GDP \\
\hline 1 & 10.3 & 40.3 & 49.4 & 12.3 & 8.5 & 79.2 \\
\hline 2 & 14.0 & 41.9 & 44.1 & 9.1 & 8.3 & 82.6 \\
\hline 3 & 18.8 & 42.8 & 38.4 & 6.0 & 7.2 & 86.8 \\
\hline 4 & 24.6 & 42.6 & 32.8 & 4.0 & 5.9 & 90.2 \\
\hline 5 & 30.7 & 41.0 & 28.3 & 3.9 & 4.5 & 91.6 \\
\hline 6 & 36.3 & 38.4 & 25.3 & 5.5 & 3.5 & 91.0 \\
\hline 7 & 40.9 & 35.3 & 23.8 & 8.1 & 2.9 & 89.0 \\
\hline 8 & 44.5 & 32.3 & 23.2 & 11.0 & 2.4 & 86.6 \\
\hline 9 & 47.2 & 29.7 & 23.1 & 13.7 & 2.1 & 84.2 \\
\hline 10 & 49.4 & 27.7 & 23.0 & 16.0 & 1.9 & 82.1 \\
\hline
\end{tabular}

Source: Authors' calculations.

\section{EXTERnal Stability Considerations ANd Regional SuRVeillance}

In the previous sections, we have argued that in addition to achieving fiscal convergence to avoid negative spillovers, the CEMAC convergence criteria should explicitly recognize the importance of short-term counter-cyclicality and long-term fiscal sustainability given members' heavy reliance on exhaustible primary commodities whose demand and price are subject to significant volatility. In this section, we further add that in light of the fixed exchange rate, the convergence criteria could be extended to considerations of external stability. 


\section{A. Consistency of the CEMAC Fiscal Convergence Criteria with External Stability}

The existing criteria on stock of public debt, domestic and external payment arrears, and inflation seem compatible with long-run external stability but they could be complemented by other indicators and a broader analysis. The ceilings on the stock of public debt and payment arrears substitute for the discipline imposed by well-functioning debt markets to prevent CEMAC members from racking up excessive debts and are therefore, also consistent with long-run external stability. The ceilings rule out opportunistic behavior by CEMAC members to amass debt (from which they solely benefit) to the point where they could no longer service it without drastic budget cuts and then rely on all CEMAC members to share the costs of debt resolution. The low inflation requirement is also consistent with long-run stability, provided that there is a sufficient positive differential between the growth of labor productivity in the CEMAC and in the European Union to compensate for the higher inflation target (i.e., less than or equal to 3 percent in the CEMAC compared with less than or equal to 2 percent in the EU). However, because the inflation criterion focuses on outcomes rather than policies, it cannot be used directly to calibrate fiscal policies. In comparison, we consider that the fiscal balance target is a necessary but not sufficient condition for external stability.

To be effective, the convergence criteria should provide insight into members' underlying economic, particularly fiscal, positions and whether they are consistent with preserving the external stability of the monetary union and the fixed exchange rate.

In this regard, the convergence criterion on the basic fiscal balance - actual and structural - is not compatible with the long-run exchange rate stability. Even if they are met, a number of concerns can arise. This is mainly due to the heavy reliance of CEMAC countries, including the C.A.R., on exhaustible resources for equilibrium in their fiscal and external balances.

- $\quad$ The overall fiscal and current account balances are not sustainable from a long-term perspective because oil revenue is temporary and it could be considered exogenous from a policy perspective, and the lack of positive impact of its decline on the non-oil economy. Unless there are new discoveries, oil revenue of CEMAC members will decline sharply over the next several decades as current reserves are depleted. Unless non-oil activity accelerates sharply to fill in the void, CEMAC members are threatened with abrupt declines in per capita income, fiscal revenue, and foreign currency export receipts. Other things being equal, the last will cause the equilibrium REER to depreciate, making the future REER overvalued relative to its level consistent with fundamentals. ${ }^{12}$

\footnotetext{
${ }^{12}$ Under these circumstances, the future equilibrium REER would depreciate, because in the absence of oil revenue the large overall fiscal and current account balances could not be sustainably financed by foreign borrowing or domestic seignorage.
} 
- $\quad$ The need for CEMAC governments to draw down the foreign asset counterpart of their deposits at the BEAC would be curtailed but not eliminated. ${ }^{13}$ The fiscal criteria could slow a decline but cannot assure constancy of the net international reserve coverage of base money in CEMAC members. Using a smoothed value for oil revenue may help build up an extra foreign currency cushion in periods of rising world oil prices but would also imply larger draw-downs of foreign assets when oil prices are falling.

- $\quad$ The REER could still become overvalued relative to its equilibrium path in the medium term because of the impact of non-oil primary fiscal deficits and domestic debt service on money growth. In Appendix I, we show that the part of the foreign-currency denominated oil revenue that is converted into CFA francs - to cover the gap between non-oil revenue and primary expenditure, plus domestic debt service - increases broad money (Equation A.4). Because the current fiscal criteria do not limit the use of oil revenue for such purposes, they contribute to the growth of money, which over time can put pressure on domestic prices and cause an appreciation of the REER. This would erode the competitiveness of CEMAC members, jeopardizing external sustainability.

\section{Considering Fiscal Policy Effects on External Balance}

When setting a target for the fiscal criterion, fiscal policy effects on external balance should be taken into consideration. This is because member countries do not have the option of nominal exchange rate or monetary policy adjustments to mitigate changes in the external environment. Instead, only fiscal policy is available (as well as structural polices, which have their impact only over a longer time frame) to ensure external stability.

There is considerable evidence suggesting that the fiscal policy stance affects the external position of the CEMAC, including the significant correlation between these elements (Figure 13). This is not surprising given that both fiscal and external balances are dominated by oil revenue and oil exports. The correlation between the overall fiscal balance and the external current account balance is 0.62 , but the correlation between the non-oil fiscal balance and the non-oil current account balance is only 0.30 .

Among the six CEMAC countries, the correlation between the fiscal and external balance is highest in Gabon (0.90) and nonexistent in the C.A.R. (Table 14 and Figure 14). Interestingly, the oil-producing countries with higher oil revenue do not necessarily show higher correlation between fiscal and external balances. It is also worthwhile to note that C.A.R., the sole non-oil

\footnotetext{
${ }^{13}$ Even if the basic balance is non-negative, governments could still need to find foreign currency financing to amortize the external public debt falling due. If foreign grants, which are excluded from the basic balance definition, are not sufficient for that purpose, governments would either need to tap new non-project external financing, or drawdown their deposits at the BEAC using the proceeds to obtain foreign currency from the regional central bank.
} 
economy, shows no correlation between fiscal and external balances: it appears the fiscal stance has little or no influence on its external balance.

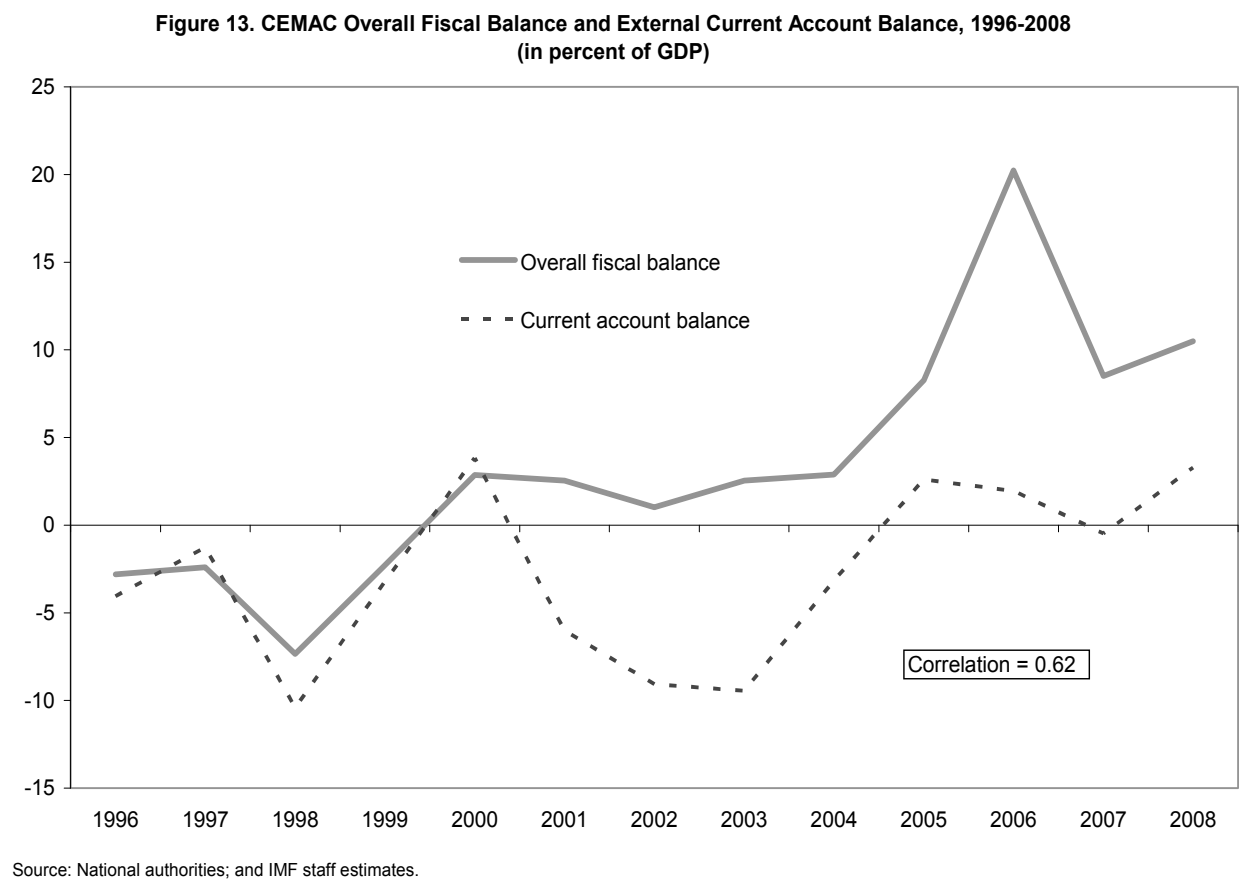

Table 14. CEMAC: Share of Oil Revenue in Total Revenue and Correlation between Fiscal and External Balances, 1996-2008

\begin{tabular}{lrr}
\hline & $\begin{array}{c}\text { Share of oil revenue } \\
(1996-2008)\end{array}$ & $\begin{array}{c}\text { Correlation } \\
(1996-2008)\end{array}$ \\
\hline CEMAC & 0.68 & 0.62 \\
Cameroon & 0.62 & 0.54 \\
C.A.R. & 0.00 & -0.02 \\
Chad & 0.55 & 0.43 \\
Congo & 0.77 & 0.40 \\
Equatorial Guinea & 0.90 & 0.75 \\
Gabon & 0.60 & 0.90 \\
\hline
\end{tabular}

Source: IMF staff estimates.

There is a more important channel through which fiscal policy affects the external position: changes in government deposits. In the CEMAC, official foreign exchange reserves are directly affected by member governments' decisions about how much to save. This is clearly indicated in the relation between the foreign assets of BEAC and member government deposits with the regional central bank (Figure 15). Although it is not possible to specify exactly what proportion of the government deposits is foreign exchange (because the currency decomposition data for government deposits are not available), a significant amount of oil receipts are supposedly denominated in foreign currency. 
Figure 14. CEMAC Countries Overall Fiscal Balance and External Current Account Balance, 1996-2008 (in percent of GDP)
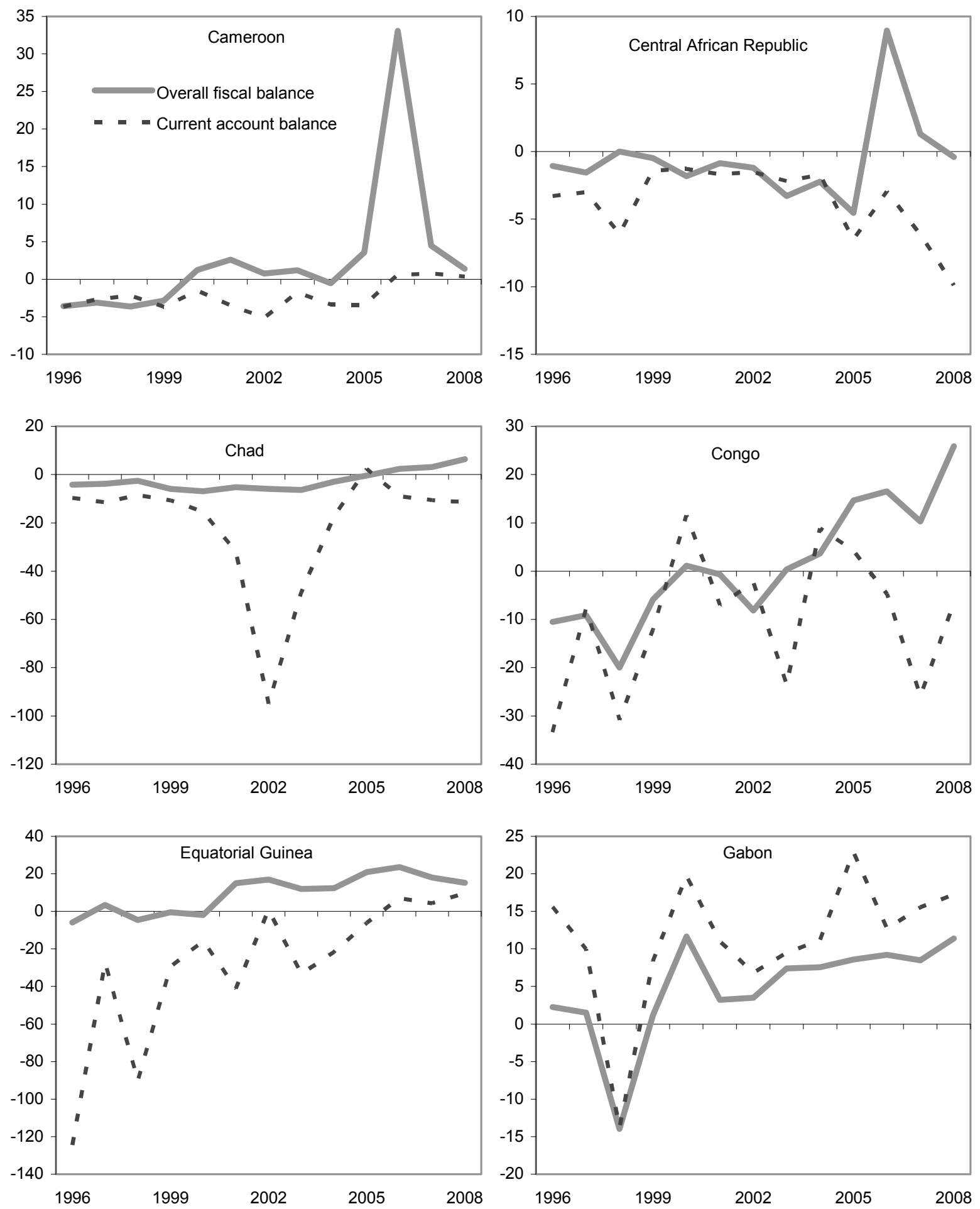

Source: IMF staff estimates. 


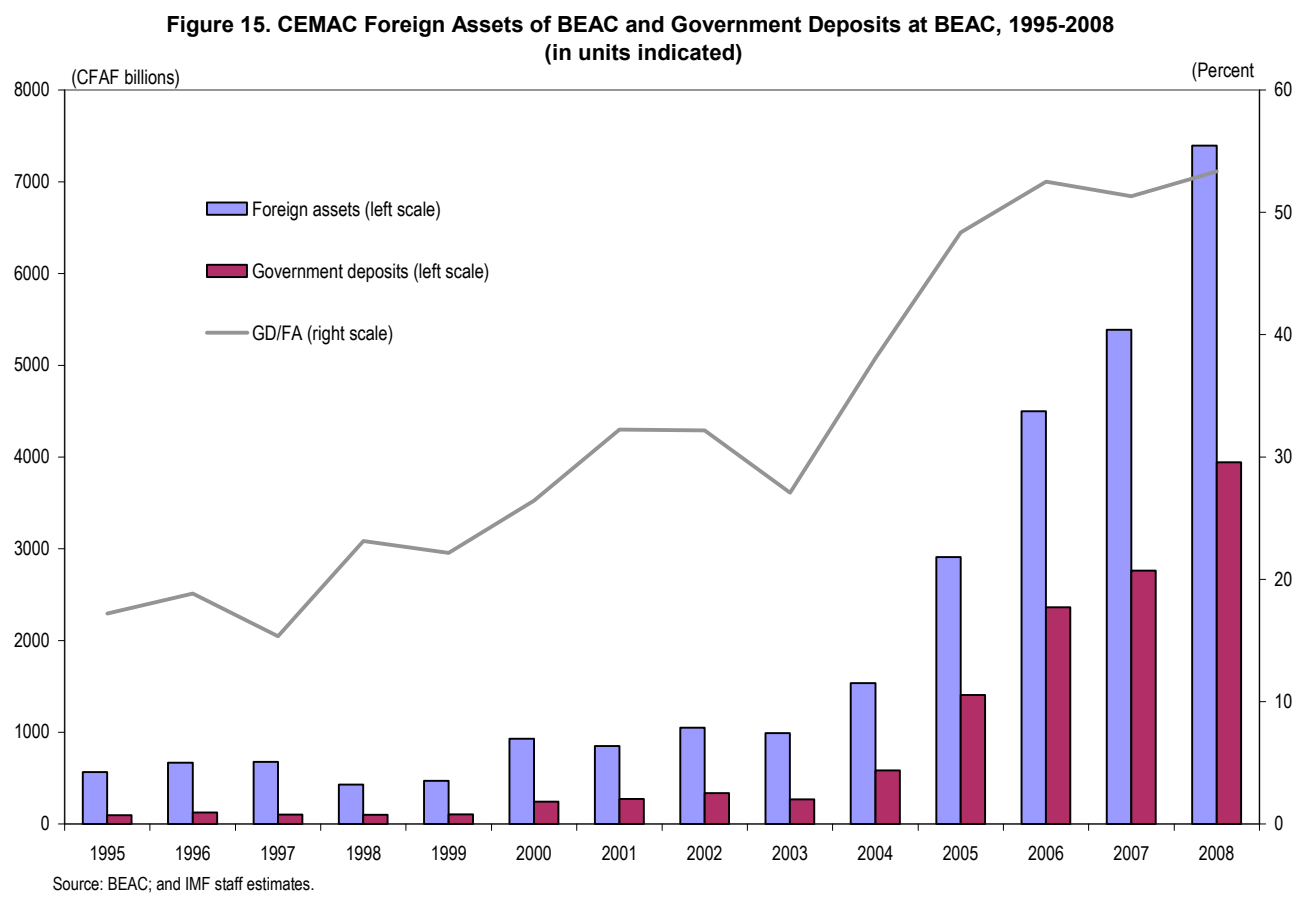

\section{Fiscal policy response to external shocks}

Currently, the CEMAC's fiscal convergence criteria do not consider external stability directly. ${ }^{14}$ Also, the fiscal policy framework of its member countries do not focus on the appropriate fiscal policy responses to external shocks as noted in Section IV above.

An appropriate fiscal policy response to a terms of trade deterioration could be to tighten from the point of view of external stability, and to loosen from the point of view of stabilizing economic activity (and internal balance). In reality, Adedeji and Williams (2008) show that the terms of trade affects the basic primary fiscal balance in the same direction. In other words, the primary fiscal balance improves when the terms of trade are favorable (and economic activities are stimulated) and deteriorates when they are unfavorable (and economic activities are dampened). Such a fiscal policy reaction may be desirable in terms of stabilizing economic activity in the face of external shocks. However, it could be counterproductive for external stability, particularly by magnifying the downside risks to external balance. One way to mitigate the problem is to accumulate a sufficient buffer of foreign reserves when external conditions are favorable.

\footnotetext{
${ }^{14}$ One could argue, however, that the ceiling on total debt-to-GDP ratio (70 percent) and the current account balance excluding grants-to-GDP ( 5 percent) do consider external balance.
} 


\section{B. The Desirability of a Foreign Reserves Target}

The BEAC statute requires members to maintain net foreign assets of at least 20 percent of sight liabilities. This raises two potential problems. The first is whether the ratio of reserves to sight liabilities (the currency-cover ratio) is appropriate for assessing external stability. The second is that because the reserve ratio is not a convergence criterion, it could suffer from the free rider problem.

Reserve adequacy can be assessed in several different ways. The relevance of the BEAC requirement could be questioned simply because it is not binding. On the other hand, it could be counterproductive if it was binding and worked against promoting financial deepening. Based on the size of terms of trade shocks and other factors, Deléchat and Martijn (2008) recommend for CEMAC members reserve coverage of four months of goods and nonfactor service imports. Relative to these norms, the reserve level of CEMAC as a whole may seem adequate in recent years, but there is a large disparity among member countries: the reserve coverage of C.A.R., Chad, Congo, and Gabon was less than four months of goods and services imports in 2007 while that of Cameroon and Equatorial Guinea is well above this level (Tables 15 and 16).

Table 15. CEMAC Currency Cover Ratio, 2000-08 (in percent) ${ }^{1}$

\begin{tabular}{|c|c|c|c|c|c|c|c|c|c|}
\hline & 2000 & 2001 & 2002 & 2003 & 2004 & 2005 & 2006 & 2007 & 2008 \\
\hline CEMAC & 71 & 65 & 68 & 66 & 75 & 88 & 96 & 98 & 103 \\
\hline Cameroon & 28 & 39 & 50 & 47 & 52 & 67 & 78 & 89 & 93 \\
\hline C.A.R. & 99 & 99 & 99 & 97 & 87 & 81 & 75 & 62 & 68 \\
\hline Chad & 78 & 80 & 88 & 74 & 70 & 64 & 91 & 90 & 93 \\
\hline Congo & 63 & 35 & 22 & 18 & 31 & 77 & 92 & 90 & 102 \\
\hline Equatorial Guinea & 61 & 98 & 102 & 100 & 100 & 100 & 100 & 97 & 98 \\
\hline Gabon & 59 & 18 & 38 & 45 & 62 & 78 & 91 & 86 & 101 \\
\hline
\end{tabular}

Table16. CEMAC Gross Official Reserves

( in months of next year's projected imports of goods and services)

\begin{tabular}{lrrrrrrrrr}
\hline & 2000 & 2001 & 2002 & 2003 & 2004 & 2005 & 2006 & 2007 & 2008 \\
\hline CEMAC & 1.9 & 1.4 & 1.7 & 1.6 & 2.3 & 3.4 & 4.7 & 5.0 & 8.0 \\
Cameroon & 1.1 & 1.4 & 2.4 & 2.0 & 2.3 & 2.3 & 3.0 & 4.5 & 5.8 \\
CAR & 8.0 & 6.9 & 7.4 & 6.7 & 6.3 & 5.4 & 4.2 & 2.4 & 3.5 \\
Chad & 1.6 & 0.7 & 1.6 & 0.9 & 1.0 & 0.9 & 2.1 & 2.8 & 4.0 \\
Congo & 1.8 & 0.5 & 0.2 & 0.2 & 0.5 & 2.3 & 4.8 & 4.7 & 10.2 \\
Equatorial Guinea & 0.2 & 0.7 & 0.5 & 1.0 & 3.2 & 7.9 & 9.7 & 7.8 & 12.0 \\
Gabon & 1.5 & 0.1 & 0.9 & 1.1 & 2.2 & 2.7 & 3.5 & 3.2 & 6.4 \\
\hline
\end{tabular}

Source: BEAC; and IMF staff estimates. 
One view would be that focusing on CEMAC reserves as a whole is the right approach in terms of encouraging efficient pooling of each country's reserves. According to this view, each member's reserve position would not affect the external stability of the CEMAC, and it would be inefficient because if each member aims to achieve the minimum, aggregate reserves would always be above the minimum. ${ }^{15}$ Another view would be that the disparities between member countries' reserves could raise a free rider problem to the extent that keeping liquidity in terms of foreign currency would be costly. The problem, if perceived excessive by a member country, could be detrimental for union cohesion in the absence of effective mechanisms for reserve pooling. It could, therefore, be suggested that the CEMAC could adopt a minimum reserve level - preferably in terms of import cover - as a convergence criterion. In this regard, the adoption of the reserve cover of the base money as a secondary criterion in the 2008 convergence evaluation is a step forward.

\section{Long-run Considerations in Regional Surveillance}

Since oil and mineral resources are exhaustible, it is necessary for long-run external stability to build a competitive non-oil (non-mineral) trade sector, a point that has been emphasized by IMF staff in previous consultations with the CEMAC (IMF, 2008). The need to save oil wealth depends on the future productivity of the non-resource trade sector. As recently suggested, CEMAC members will have to save half to two-thirds of their oil revenue (IMF, 2008). This may seem extreme and it is evident the results may be sensitive to a variety of assumptions, particularly on the future productivity of the non-resource sector; but the point is worth noting, especially in the context of volatility and uncertain direction of world oil prices.

Consequently, surveillance in the CEMAC region might also be directed at monitoring developments in the non-resource sector. A key here is converting exhaustible resources into physical and human capital and productivity gains in reproducible sectors - which is a long-run challenge. Here, there is a central role for fiscal policy, particularly to raise the efficiency of the tax and tariff systems, and improve expenditure prioritization and its quality. Although such elements might be hard to capture as quantitative criteria, it is worth highlighting in the regional surveillance.

\section{SUMmary AND Policy IMPLiCATIONS}

The CEMAC is undertaking a long-term process of regional integration, with the intention of creating a common market based on the free movement of goods and services, capital and labor, and to harmonize business laws and coordinate economic policies. This is a worthwhile

\footnotetext{
${ }^{15}$ Technically, imports for CEMAC are smaller than the sum of imports of the member countries because of intraregional trade. This could be another reason why the level of reserves adequate for CEMAC may be smaller than the sum of adequate reserves for each member. However, intraregional trade is relatively small and probably does not alter reserve levels significantly.
} 
initiative, given the benefits of closer integration in the context of a monetary union with a fixed exchange rate. Progress in moving forward with closer ties, however, has been slow. A number of factors may explain this slowness; the impact of external shocks that have buffeted the region and has frustrated better economic performance and convergence; domestic instability from frequent internal conflicts; and the lack of political leadership at the level of the union. A further contributing factor may be weaknesses in regional surveillance and the convergence criteria. In our view, the surveillance agenda could be sharpened to elaborate in more detail members' underlying economic conditions, how external factors are influencing developments, and the policy stance. Hopefully, more effective "peer review" would lead to better policy performance.

In taking a broad approach to regional surveillance, we find that CEMAC's convergence criteria are rather limited and provide an incomplete picture of the policies and other forces acting, and offer little insight on whether policies are consistent with preserving the external stability of the monetary union and the fixed exchange rate. To be more effective, the CEMAC's surveillance agenda could be sharpened in a number of ways.

The main fiscal convergence criterion for the CEMAC region, a non-negative basic balance, does not provide a reliable benchmark against which to judge short-term changes in fiscal policy or long-term fiscal sustainability in member countries. This criterion suffers from at least two shortcomings. First, it fails to take into account an economy's cyclical position. Second, it fails to recognize that five of the six CEMAC countries are oil-producers and that income from exhaustible oil resources should be treated as financing instead of revenue, from the point of view of good resource-wealth management.

While the majority of the CEMAC countries met the convergence criterion on the basic fiscal balance and one of the two associated adjustment criteria with comfortable margins, an indicator of fiscal stance and fiscal impulse suggest that fiscal policies in all CEMAC countries have been strongly expansionary during 2005-08 if cyclical fluctuations and oil revenue are appropriately removed. In addition, from the perspective of long-term sustainability, the majority of member countries' non-oil primary deficits are far higher than the sustainable level under various fiscal rules.

We would argue that fiscal surveillance at both the regional and individual country level, should not rely entirely on the current convergence criteria. Instead, the fiscal indicators excluding oil revenue, such as the non-oil fiscal stance, non-oil fiscal impulse, and non-oil primary balance, should receive central attention. In this regard, we welcome the CEMAC Commissions' introduction of an adjustment criterion on the non-oil basic fiscal balance but to make it effective, this criterion would need to be refined. Ideally, each economy's cyclical position should be considered as well, although we recognize the practical difficulties in applying cyclical adjustments in a transparent and uniform way across all member countries. With five of the six countries being oil-producers long-term fiscal sustainability is also a concern, which could be monitored through analysis based on simple fiscal rules. 
CEMAC countries have been faced with external shocks that have been shown to have a significant and variable impact across member countries, which complicate economic and especially fiscal policies. Indeed, the current fiscal convergence criteria do not address the procyclial nature of CEMAC fiscal polices, which can exaggerate the impact of external shocks. Since discretionary fiscal policy is demonstrated to have the ability to mitigate the impact of external shocks across the region, it is important to take this factor into account when assessing and formulating the relevant convergence criteria. This point was stressed in evaluating alternative fiscal indicators, and it was noted that the current convergence criteria do not allow for the possibility of a counter-cyclical fiscal stance to address a downturn or an adverse external shock.

Also, CEMAC's surveillance agenda will need to consider the impact of fiscal policy on external stability, especially under the fixed exchange rate regime. Here, building sufficient reserve coverage is important and in periods of high world oil prices when there is a windfall of oil revenue. In this regard, the existing minimum requirement as a non-obligatory secondary criterion on the currency coverage ratio (20 percent) is likely to be inadequate; this indicator may not be appropriate to define reserve adequacy in the face of the external shocks buffeting the region. One clear possibility to address this concern is to reexamine reserve adequacy based on the ongoing work at the BEAC and to consider a relevant convergence criteria. When setting a desirable reserve target level, consideration could be given to creating space for the fiscal stance to respond to changes in external (as well as domestic) conditions. To address long-term external stability, the regional surveillance exercise could cover structural aspects of fiscal policy so that the tax and spending system would be supportive of capital accumulation and productivity gains in reproducible sectors.

Ultimately, the external viability of the monetary union and its fixed exchange rate depends on the strength of fiscal policies and structural reform to build vibrant and viable non-oil sectors in the member countries. Only in this way will the union generate enough foreign exchange to finance the imports needed to maintain moderate levels of growth and real income. 


\section{ApPendix: Linkages Between Fiscal and Monetary Policies in a Non-Renewable Resource Producer under a}

FiXED EXCHANGE RATE

\section{- Government budget constraint (in domestic currency units)}

$S \cdot \operatorname{Rev}^{*}+\operatorname{Rev}^{N R}-\operatorname{Exp}_{p}+S \cdot r^{*} \cdot N F A_{G, t-1}^{*}+r \cdot N D A_{G, t-1}^{B}+r \cdot N D A_{G, t-1}^{N B}+\Delta A r r_{G}-S \cdot \Delta N F A_{G}^{*}-\Delta N D A_{G}^{B}-\Delta N D A_{G}^{N B}=0$

$S$ - average exchange rate (domestic currency units per one unit of foreign currency);

$S \cdot \operatorname{Rev}^{*} ; \operatorname{Rev}^{N R}$ - government revenue from the resource sector (assumed to be in foreign currency only), and the nonresource sector, respectively;

$\operatorname{Exp}_{p}$ - government primary expenditures (on goods and services produced by the foreign sector, and on wages, transfers and subsidies to, and goods and services from the domestic non-resource sector);

$S \cdot r^{*} \cdot N F A_{G, t-1}^{*} ; r \cdot N D A_{G, t-1}^{B} ; r \cdot N D A_{G, t-1}^{N B}$ - net interest payments received by the government on its net assets (assets minus liabilities) vis-à-vis the foreign sector (assumed to be in foreign currency only), and the bank and non-bank non-resource domestic sectors, respectively. For simplicity, it is assumed that the interest rate accrued on both assets and liabilities is the same;

$\Delta A r r_{G}$ - change in government arrears (+ indicates an increase);

$S \cdot \Delta N F A_{G}^{*} ; \Delta N D A_{G}^{B} ; \Delta N D A_{G}^{N B}$ - change in net foreign assets (assets minus liabilities) of the government vis-à-vis the foreign sector (assumed to be in foreign currency only) and change in net domestic assets of the government vis-à-vis the bank and non-bank non-resource domestic sectors, respectively;

$\Delta N D A_{G}^{B}=S \cdot\left(\operatorname{Rev}^{*}+r^{*} \cdot N F A_{G, t-1}^{*}-\Delta N F A_{G}^{*}\right)-\left(\operatorname{Exp}_{p}-\operatorname{Rev}^{N R}\right)-\left(\Delta N D A_{G}^{N B}-r \cdot\left(N D A_{G, t-1}^{B}+N D A_{G, t-1}^{N B}\right)\right)+\Delta A r r_{G}$

- Variables under government control: non-resource primary fiscal deficit $\left(\operatorname{Exp}_{p}-\operatorname{Rev}^{N R}\right)$ and $\operatorname{arrears}\left(\triangle A r r_{G}\right)$;

- Variables outside government control: government revenue from the resource sector $\left(S \cdot \operatorname{Rev}^{*}\right)$ and debt service $\left(\Delta N D A_{G}^{N B}+\Delta N F A_{G}^{*}-r \cdot\left(N D A_{G, t-1}^{B}+N D A_{G, t-1}^{N B}\right)-r^{*} \cdot N F A_{G, t-1}^{*}\right)$, assuming that the government does not place assets abroad and does not borrow directly from the non-bank non-resource domestic sectors; 
- Domestic bank sector (central bank and commercial banks) constraint (in domestic currency units)

$\Delta M=S \cdot \Delta N F A_{B}^{*}+\Delta N D A_{B}^{N B}+\Delta N D A_{B}^{G}$, where

$\Delta M$ - change in broad money;

$S \cdot \Delta N F A_{B}^{*}$ - change in net foreign assets of the domestic bank sector vis-à-vis the foreign sector (assumed to be in foreign currency only);

$\Delta N D A_{B}^{N B} \equiv \Delta D C_{B}^{N B}+\Delta O I N$ - change in net domestic assets of the domestic bank sector vis-à-vis the non-bank, non-resource sector. By definition, it is equal to the change in domestic credit of the domestic bank sector to the non-bank, non-resource sector and the change in other items net;

$\triangle N D A_{B}^{G}$ - change in net domestic assets of the domestic bank sector vis-à-vis the government ;

$\Delta N D A_{B}^{G} \equiv-\Delta N D A_{G}^{B}$ - by definition, the change in net domestic assets of the banking sector vis-à-vis the government is equal to the negative of the change in net domestic assets of the government vis-à-vis the bank sector (equation A.2);

$\Delta M=S \cdot \Delta N F A_{B}^{*}+\Delta D C_{B}^{N B}+\Delta O I N-\left(S \cdot\left(\operatorname{Rev}^{*}+r^{*} \cdot N F A_{G, t-1}^{*}-\Delta N F A_{G}^{*}\right)-\left(\operatorname{Exp}_{p}-\operatorname{Rev}^{N R}\right)-\left(\Delta N D A_{G}^{N B}-r \cdot\left(N D A_{G, t-1}^{B}+N D A_{G, t-1}^{N B}\right)\right)+\Delta A r r_{G}\right)$

- Interlinkage between monetary and fiscal policy

$\Delta M=\left(\operatorname{Exp}_{p}-\operatorname{Rev}^{N R}\right)-\Delta A r r_{G}+\Delta O I N+\left(\Delta D C_{B}^{N B}+S \cdot\left(\Delta N F A_{B}^{*}-\left(\operatorname{Rev}^{*}+r^{*} \cdot N F A_{G, t-1}^{*}-\Delta N F A_{G}^{*}\right)\right)\right)+\left(\Delta N D A_{G}^{N B}-r \cdot\left(N D A_{G, t-1}^{B}+N D A_{G, t-1}^{N B}\right)\right)$

- Variables under government control: non-resource primary fiscal deficit $\left(\operatorname{Exp}_{p}-\operatorname{Rev}^{N R}\right)$ and $\operatorname{arrears}\left(\Delta \operatorname{Arr}_{G}\right)$;

- Variables outside government control: change in broad money resulting from financial transactions by the non-bank, non-resource sector with the domestic banking sector and the foreign sector $\left(\Delta D C_{B}^{N B}+S \cdot\left(\Delta N F A_{B}^{*}-\left(\operatorname{Rev}^{*}+r^{*} \cdot N F A_{G, t-1}^{*}-\Delta N F A_{G}^{*}\right)\right)\right)$ and the domestic debt service $\left(\Delta N D A_{G}^{N B}-r \cdot\left(N D A_{G, t-1}^{B}+N D A_{G, t-1}^{N B}\right)\right)$.

- Variables potentially under the influence of the central bank: change in other items net $(\Delta O I N)$, through open market operations or changes in bank capital requirements. 


\section{References}

Barnett, Steven and Rolando Ossowski, 2003, "Operational Aspects of Fiscal Policy in Oil-Producing Countries," in Fiscal Policy Formulation and Implementation In Oil-Producing Countries ed. By Jeffery Davis, Rolando Ossowski, and Annalise Fedelino (Washington: International Monetary Fund), pp. 45-81.

Bayoumi, T., and J. D. Ostry, 1995, "Macroeconomic Shocks and Trade Flows Within Sub Saharan Africa: Implications for Optimum Currency Arrangements," IMF Working Paper No. 95/142 (Washington: International Monetary Fund).

Blanchard, Olivier (1990), "Suggestions for a New Set of Fiscal Indicators", OECD Economics Department Working Papers, No. 79 (Paris: Organization for Economic Co-Operation and Development).

Blanchard, Olivier and Robert Perotti, 2003, "An Empirical Characterization of the Dynamic Effects of Changes in Government Spending and Taxes on Output", Quarterly Journal of Economics, Vol. 117, No. 4, pp.1329-1368.

Broda, Christian, 2003, “Terms of Trade and Exchange Rate Regimes in Developing Countries", Federal Reserve Bank of New York Staff Reports, No 148, and Journal of International Economics.

Buiter, Willem, "Measurement of the public Sector Deficit and its Implications for Policy Evaluation and Desing”, Staff Papers Vol. 24 (Washington: International Monetary Fund).

Buiter, Willem, Giancarlo Corsetti, and Roubini, Nouriel, 1993, "Excessive Deficits: Sense and Nonsense in the Treaty of Maastricht," Economic Policy, 16, Apr., pp. 58-100.

BOF, 2007, Rapport Zone franc, www.banque-france.fr/fr/eurosys/zonefr/page2_2007.htm, (Paris: Banque de France).

Bordo, Michael, 2003, "Exchange Rate Regime Choice in Historical Perspective," NBER Working Paper 9654, www.nber.org/papers/w9654, (Cambridge, MA: National Bureau of Economic Research).

Boughton, James, 1991, "The CFA Franc Zone: Currency Union and Monetary Standard," IMF Working Paper No. 91/133 (Washington: International Monetary Fund).

Chand, Sheetal (1992), "Fiscal Impulses and their Fiscal Impact", IMF Working Paper WP/92/38 (Washington: International Monetary Fund). 
Collier, Paul (1991), “Africa’s External Economic Relations, 196-90”, Africa Affairs Vol. 90, July, pp. 339-56.

Deléchat, Corinne and Jan Kees Martjin, 2008, "Reserve Adequacy in the CFA Franc Zone," in Gulde and Tsangarides eds, The CFA Franc Zone-Common Currency, Uncommon Challenges, pp.90-119.

ECA, 2004a, Assessing Regional Integration in Africa, www.uneca.org/aria/ (Addis Ababa: Economic Commission for Africa).

ECA, 2004b, Assessing Regional Integration in Africa III, www.uneca.org/aria/ (Addis Ababa: Economic Commission for Africa).

Elbadawi, I. and N. Majd, 1992, "Fixed Parity of the Exchange Rate and Economic Performance in the CFA Zone: a Comparative Study," World Bank Policy Research Working Paper No. 830, http://EconPapers.repec.org/RePEc:wbk:wbrwps:830 (Washington: The World Bank).

Frankel, Jeffrey and Rose, Andrew, 1998, "The Endogeneity of Optimum Currency Area Criteria," The Economic Journal, 108(449), Jul, pp. 1009-25.

Friedman, Milton, 1957, A Theory of the Consumption Function (Princeton: Princeton University Press).

Hadjimichael, Michael and Galy, Michel, 1997, “The CFA Franc Zone and the EMU,” IMF Working Paper No. 97/156 (Washington: International Monetary Fund).

Hawkins, John and Masson, Paul, 2003, "Economic aspects of regional currency areas and the use of foreign currencies," in Regional Currency Areas and the Use of Foreign Currencies, BIS Papers 17, www.bis.org/publ/bppdf/bispap17.pdf (Basel: Bank for International Settlements).

Heller, Peter, Richard Haas, and Ahsan Mansur (1986), “A Review of the Fiscal Impulse Measure”, IMF Occasional Paper No. 44 (Washington: International Monetary Fund).

International Monetary Fund (2008), Central African Economic and Monetary Community, Selected Issues.

Jacobs, Davina (2002), "Suggestions for AlternativeMeasures of Budget balance for South Africa", IMF Working Paper WP/02/110 (Washington: International Monetary Fund) 
Kenen, Peter, 1969, "The Theory of Optimum Currency Areas: An Eclectic View," in Robert Mundell and Alexander Swoboda, eds, Monetary Problems in the International Economy, pp. 41-60, (Chicago: University of Chicago Press).

Konaté, Adama, 2001, "Challenges Facing the CFA Franc," BNP Paribas Conjoncture, October, (Paris: BNP Paribas).

McKinnon, Ronald, 1963, “Optimum Currency Areas,” American Economic Review, 53(4), Sept., pp. 717-25.

McKinnon, Ronald, 2004, "Optimum Currency Areas and Key Currencies: Mundel I versus Mundell II," Journal of Common Market Studies, 42(4), pp. 689-715.

Maruping, Mothae, 2005, "Challenges for Regional Integration in Sub-Saharan Africa: Macroeconomic Convergence and Monetary Coordination," in Jan Teunissen and Age Akkerman (editors) Africa in the World Economy The National, Regional and International Challenges, www.fondad.org/publications/africaworld (Amsterdam: FONDAD).

Masson, Paul and Catherine Patillo, 2005, The Monetary Geography of Africa, www.brookings.edu/papers/2003/1017globaleconomics_masson.aspx (Washington: Brookings Institution Press).

Mundell, Robert, 1961, “A Theory of Optimum Currency Areas,” American Economic Review, 51(4), Sept., pp. 657-65.

RMFZF, 2008a, La convergence économique en Zone franc, April, www.banquefrance.fr/fr/eurosys/telechar/zonefr/convergence eco_ZF.pdf (Paris: Réunion des ministres des Finances de la Zone franc).

RMFZF, 2008b, Comite de convergence : Rapport aux Ministres, October, www.banquefrance.fr/fr/eurosys/telechar/zonefr/rapp_ministr.pdf (Paris: Réunion des ministres des Finances de la Zone franc).

Stasavage, David, 1997, “The CFA Franc Zone and Fiscal Discipline," Journal of African Economies, 6(1), Mar, pp. 132-67.

Schinasi, Gary and Mark Lutz (1991), "Fiscal Impulse”, IMF Working Paper WP/91/91 (Washington: International Monetary Fund).

Tornell, Aron and Andrés Velasco (2000), "Fixed Versus Flexible Exchange Rates: Which Provides More Fiscal Discpline?", Journal of Monetary Economics, 45, pp.399-436. 
Truman, Edwin, M., 2006, "Budget and External Deficits: Not Twins but the Same Family," in Kopcke et al eds., The Macroeconomics of Fiscal Policy, pp. 299-319.

Von Hagen, Jurgen, 1992, "Fiscal Arrangements in a Monetary Union: Evidence from US," in Paul De Grauwe, ed., 2001, The Political Economy of Monetary Union, (Cheltenham, UK: Edward Elgar).

York, Robert and Zaijin Zhan, 2009, "Fiscal Vulnerability and Sustainability in OilProducing Sub-Saharan African Countries, IMF Working Paper WP/09/174, (Washington: International Monetary Fund). 